\title{
Intratumoural inflammation and endocrine resistance in breast cancer
}

\author{
Jill I Murray ${ }^{1}$, Nathan R West ${ }^{2}$, Leigh C Murphy ${ }^{3}$ and Peter H Watson ${ }^{1,4,5}$ \\ ${ }^{1}$ Deeley Research Centre, British Columbia Cancer Agency, 2410 Lee Avenue, Victoria, British Columbia, \\ Canada V8R 6V5 \\ ${ }^{2}$ Translational Gastroenterology Unit, Nuffield Department of Medicine, John Radcliffe Hospital, \\ University of Oxford, Oxford, UK \\ ${ }^{3}$ Department of Biochemistry and Medical Genetics and the Manitoba Institute of Cell Biology, \\ University of Manitoba and CancerCare Manitoba, 675 McDermot Avenue, Winnipeg, Manitoba, Canada \\ ${ }^{4}$ Department of Biochemistry and Microbiology, University of Victoria, Victoria, British Columbia, Canada \\ ${ }^{5}$ Department of Pathology and Laboratory Medicine, University of British Columbia, Vancouver, \\ British Columbia, Canada
}

Correspondence should be addressed to $\mathrm{P} \mathrm{H}$ Watson

Email pwatson@bccancer.bc.ca

\begin{abstract}
It is becoming clear that inflammation-associated mechanisms can affect progression of breast cancer and modulate responses to treatment. Estrogen receptor alpha (ER $\alpha(E S R 1))$ is the principal biomarker and therapeutic target for endocrine therapies in breast cancer. Over $70 \%$ of patients are ESR1-positive at diagnosis and are candidates for endocrine therapy. However, ESR1-positive tumours can become resistant to endocrine therapy. Multiple mechanisms of endocrine resistance have been proposed, including suppression of ESR1. This review discusses the relationship between intratumoural inflammation and endocrine resistance with a particular focus on inflammation-mediated suppression of ESR 1.
\end{abstract}

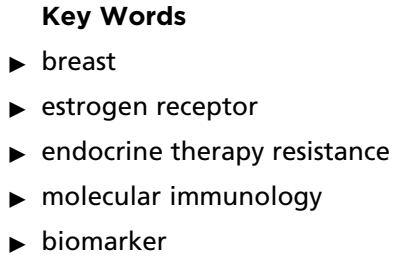

Endocrine-Related Cancer (2015) 22, R51-R67

\section{Introduction}

The association between inflammation and cancer has long been established. Inflammatory cells are commonly found in tumour tissues and chronic inflammation is associated with many cancers, including breast cancer, and is capable of affecting tumour progression and differentiation of tumor cells (Coussens \& Werb 2002, Balkwill et al. 2005, Reiman et al. 2007, Pages et al. 2010, Hanahan \& Weinberg 2011, Balkwill \& Mantovani 2012). The immune system can exert both pro- and anti- tumour effects in breast cancer. For example, multiple studies have shown that $\mathrm{CD}^{+}$tumor-infiltrating lymphocytes (TIL) are associated with improved outcome in breast cancer (Mahmoud et al. 2011, Liu et al. 2012), particularly in estrogen-receptor-negative breast cancer where TILs are often present in higher numbers (Teschendorff et al. $2007 a, b)$. However, it is increasingly clear that inflammation-associated tumour-promoting mechanisms can also be a factor in breast cancer progression (Baumgarten \& Frasor 2012, Coussens et al. 2013, Jiang \& Shapiro 2014). Perhaps more significant are the results of studies that have indicated that inflammation mediates or modifies the response to treatment (Desmedt et al. 2008, DeNardo et al. 2011, West et al. 2011, Andre et al. 2013, Zitvogel et al. 2013). However, intratumoural inflammation, like the neoplastic process that stimulates it, is a complex process and we know relatively little of the specific pathways that connect them.

In breast cancer, the estrogen receptor alpha (Er $\alpha$ (ESR1)) is an important target for a group of therapies collectively known as endocrine therapies. The ESR1 is a nuclear transcription factor that not only guides and serves as a target for endocrine therapies, but also occupies a central position in subtype classification and role in breast cancer biology. Nevertheless, the mechanisms that

Published by Bioscientifica Ltd. 
regulate the expression and activity of ESR1 in breast cancer are not well understood (Zwart et al. 2011). ESR1positive tumours account for approximately $70 \%$ of cases at diagnosis and are candidates for endocrine therapies. However, ESR1-positive tumours can manifest resistance at the outset or become resistant to endocrine therapy over time. There have been many reviews describing the clinical problem of endocrine therapy resistance in breast cancer as well as advances in understanding the mechanisms underlying this resistance (Musgrove \& Sutherland 2009, Osborne \& Schiff 2011, Baumgarten \& Frasor 2012, Sas et al. 2012, Patani \& Martin 2014). Much attention has been focused on mechanisms that short-circuit the ESR1 pathway downstream of the receptor and those arising from altered activities of intracellular kinase pathways. Yet factors and mechanisms that change the expression of the ESR1 itself are clearly present in some instances and may also be important (Lapidus et al. 1998, Stearns et al. 2007). We consider here the possibility that inflammationderived-cytokine signalling plays an important and hitherto under-explored role in the suppression of ESR1 levels. This possibility is supported by strong correlations between intratumoural inflammation and ESR1-low or ESR1-negative status of breast tumours, which are readily observed in clinical practice. However, a specific mechanism to explain this observation and to connect it with acquired resistance to endocrine therapy and increased invasive properties has been lacking. In other words, how does the immune system, and the intratumoural inflammatory response that it directs, affect the level of ESR1 in breast cancer? Also, does chronic inflammation affect response to endocrine therapy?

\section{ESR1 is a predictive biomarker in breast cancer}

Advances in knowledge regarding breast cancer over several decades have resulted in therapies, such as those targeting the ER and the epidermal growth factor receptor 2 (HER2), that specifically benefit the subsets of patients defined by these biomarkers. ESR1 in particular is now well established as a central biomarker for prescribing treatment programmes, and targeted inhibitors of ER signalling have been the mainstay of breast cancer therapy for over 30 years. However, development of resistance curtails the effectiveness of such therapies (Gee et al. 2005, Osborne \& Schiff 2011). ESR1 is a transcription factor that is routinely measured by immunohistochemical (IHC) assays to determine clinical ER status (ER-positive or ER-negative) and to guide endocrine therapy (Murphy \& Watson 2002). Endocrine therapy is often deployed when primary tumours are classified as ER-positive and mostly revolves around the use of drugs that either block the estrogen growth stimulus directly at the level of ER (selective ER modulators/downregulators (SERMs/SERDs)) or indirectly by inhibition of estrogen production (aromatase inhibitors (AIs); Lewis \& Jordan 2005, Cheang et al. 2008).

The clinical designation, 'ER status' is based on assays that assess expression levels of only one ER, the classical ESR1. However, it is now recognised that the definition of clinical ER status is more complex, and that many tumour cells express a second type of ER, ER $\beta$ (ESR2; Hartman et al. 2009 ) that may differentially affect ER signalling in distinct cellular contexts (discussed in more detail in a later section). Multiple isoforms of both ERs and their phosphorylation status also complicate the picture (Skliris et al. 2008, 2010, Murphy et al. 2011, Murphy \& Leygue 2012). It is becoming evident that the measurement of additional indicators such as phosphorylation of ESR1 and ESR2 may also be needed to fine-tune the predictive value of ER status (Hartman et al. 2009, Murphy \& Leygue 2012). It is also well known that there can be heterogeneous expression of ESR1 across tumours that are clinically ER-positive. Homogeneous and 'strongly' ER-positive tumours generally have better response rates to endocrine therapy in comparison with heterogeneous and 'weakly' ER-positive tumours (Goldhirsch et al. 2009). However, tumours with as few as $1 \%$ of the tumour cells staining positive by IHC are considered ER-positive for the purpose of clinical decisions and can be responsive to endocrine therapy (Hammond et al. 2010).

\section{Mechanisms of resistance to endocrine therapy}

At clinical presentation, approximately $70 \%$ of primary tumours are categorised as ER-positive and approximately $30 \%$ as ER-negative. The former are regarded as potentially responsive to endocrine therapy (Musgrove \& Sutherland 2009), while the latter are regarded as intrinsically resistant and not eligible. However, it is now recognised that hormone-receptor-positive tumours are very heterogeneous at both the clinical (Lim et al. 2012, Nagaraj et al 2012) and molecular levels (Curtis et al. 2012, Ellis et al. 2012) and that ER-positive tumours often exhibit a spectrum of response at the outset. Many eventually develop acquired resistance that leads to tumour recurrence despite continued therapy (Early Breast Cancer Trialists' Collaborative Group (EBCTCG) 2005). Furthermore, metastasis dormancy is problematic in ER-positive cancer (Zhang et al. 2013) and predicting resistance remains a major challenge.

Published by Bioscientifica Ltd. 
Endocrine resistance may have many underlying causes that differ between intrinsic and acquired circumstances (Gee et al. 2005, Osborne \& Schiff 2011). In general, resistance may be considered to reflect three possible mechanisms: i) overactivity of coregulators and/or kinase pathways that alter signalling downstream of ER; ii) the emergence and dominance of a minor ER-negative cell population harboured within a heterogeneously ER-positive tumour (Stearns et al. 2007, Brinkman \& El-Ashry 2009) and iii) plasticity and partial conversion from ER-positive to ER-negative tumour cell differentiation (Doane et al. 2006, Massarweh et al. 2006).

When resistance occurs despite ER-positive status at diagnosis or persistence of ESR1 expression at recurrence, it is likely to be attributable to mechanisms that lie downstream of ESR1, such as overactivity of kinase pathways or altered expression of ESR1 coregulators (Murphy et al. 2002, Schiff et al. 2004, Gee et al. 2005). This can occur at the level of systemic growth factors (e.g. EGF, heregulin and amphiregulin) that stimulate signalling, at the level of receptor kinases themselves (e.g. EGFR, ERBB2 and IGF1R/IR) and at the level of signalling pathways downstream of receptor tyrosine kinases (e.g. PI3K, AKT, MAPK and MTOR). Increases in growth factor receptor expression levels (e.g. ERBB2) can lead to ligand-independent ESR1 activation and tamoxifen resistance (Shou et al. 2004). Activation of EGFR and ERBB2 can also stimulate MAPK14 (p38) and MAPK1/ MAPK3 (ERK1/2) MAPK signalling, leading to altered crosstalk with ESR1 signalling and endocrine resistance (Gutierrez et al. 2005, Arpino et al. 2008, Patani \& Martin 2014). PI3K and AKT signalling, downstream of growth factor receptor tyrosine kinases, contributes to tamoxifen resistance by modulating phosphorylation and activation of ESR1, co-activator activity and progesterone receptor levels (Bunone et al. 1996, Cui et al. 2003, 2005, Faridi et al. 2003, deGraffenried et al. 2004, Miller et al. 2011). Phosphorylation and amplification of co-activators, such as NCOA3, can also lead to increased ligand-independent activity and endocrine resistance (Osborne et al. 2003, Antoon et al. 2012).

\section{Loss of ESR1 in breast cancer}

When resistance occurs in conjunction with reduction and/or loss of ESR1 in the tumour (as occurs in 25-30\% of cases with acquired resistance (Johnston et al. 1995, Kuukasjarvi et al. 1996, Broom et al. 2009)), it is likely to be attributable to changes in overall cell phenotype or to a more focused alteration in ESR1 regulation.
Overall change in cell phenotype, or 'tumour cell plasticity', with respect to the evolution of molecular subtypes is one possibility (Doane et al. 2006, Massarweh et al. 2006). It is known that the molecular phenotype can be altered through the actions of single master regulators such as FOXA1 and ELF5 (Bernardo et al. 2010, 2013, Kalyuga et al. 2012), and that approximately $10 \%$ of triple-negative tumours (clinically negative for ESR1, progesterone receptor (PGR) and ERBB2) manifest luminal-like gene expression profiles (Creighton et al. 2006, Bertucci et al. 2012). Downregulation of the transcription factor and chromatin remodelling factor FOXA1 results in downregulation of ESR1 in MCF7 cells (Bernardo et al. 2010). FOXA1 represses basal gene expression patterns in luminal cell lines, and silencing FOXA1 can shift the transcriptional balance away from a luminal gene expression profile and towards a basal-like state (Bernardo et al. 2013). Forced expression of the transcription factor ELF5 was also shown to reduce ER and estrogen responsiveness and induce a gene expression signature associated with ER-negative status, thus potentially contributing to endocrine resistance (Kalyuga et al. 2012, Frend \& Watson 2013). As yet another mechanism, it has been suggested that an ER-negative phenotype with luminal and basal features can emerge from ER-positive luminal tumours during endocrine therapy through a notch-dependent process (Haughian et al. 2012).

Specific alteration at the level of the ER is another possibility. At diagnosis, it is possible that some clinically ER-positive breast tumours that have low levels of ESR1 expression, or some ER-negative status tumours with overall gene expression profiles akin to luminal subtype tumours (e.g. the 'LAR' subtype; Lehmann et al. 2011, Nagaraj et al. 2012, Peddi et al. 2012), may in fact represent 'ER suppressed' tumours. This is supported by expression array analysis that identified subsets of ER-negative tumours (comprising approximately 25\% of ER-negative tumours) that share overall gene expression profiles with subsets of ER-positive tumours but lack apparent ER expression (Creighton et al. 2006, Lehmann et al. 2011, Nagaraj et al. 2012). Although this may be in part due to the expression of androgen receptor and its binding to and regulating ESR1 cis-regulatory elements in apocrine tumour subsets (Robinson et al. 2011), this cannot explain all cases.

Downregulation or suppression of ESR1 in the breast tumour cell can be caused by both internal and external factors. The former include factors associated with epithelial-to-mesenchymal transition (EMT) and related signalling. The EMT-related transcription factor Twist has been shown to down-regulate the expression of ESR1 expression

Published by Bioscientifica Ltd 
by recruiting DNA methyltransferase $3 \mathrm{~B}$ and histone deacetylase 1 to the ER promoter region, resulting in endocrine resistance (Vesuna et al. 2012). Another prominent EMT-related transcription factor, Snail, has also been implicated in ER suppression and endocrine resistance (Dhasarathy et al. 2007). Other internal cellular factors include acquired intracellular alterations in kinase signalling pathways (Brodie et al. 2005, Massarweh et al. 2006, Creighton et al. 2010, Giamas et al. 2011), trans-repression through upregulation of NFKB (Pradhan et al. 2012, Sas et al. 2012), effects of proteasome targeting factors (Man \& Zhang 2011, Pan et al. 2011) or microRNA expression (Guttilla et al. 2012). Finally, suppression of ESR1 can also be caused by various extracellular factors including growth factors and cytokines (to be discussed below).

Intriguingly, results from multiple studies have established that ER suppression and endocrine resistance can be reversible processes and that inhibition of MAPK signalling leads to restoration of ESR1 expression, ER function and tamoxifen responsiveness (Oh et al. 2001, Bayliss et al. 2007, Riggins et al. 2007, Antoon et al. 2013). El-Ashry and colleagues have shown that hyperactivity of MAPK signalling downregulates ESR1 and causes features of endocrine resistance. Briefly, EGFR receptor tyrosine kinase signalling in breast cancer cell lines led to activated RAS and downstream MAPK1/MAPK3 (ERK1/2) MAPK signalling affecting ER at both the mRNA and protein levels. Re-expression of ER in ER-negative breast cancer cell lines was achieved by intracellular inhibition of MAPK1/MAPK3 (ERK1/2) MAPK signalling (with the small-molecule inhibitor U0126) or by blocking extracellular growth factor signalling to the cell with Iressa (EGFR) or Herceptin (ERBB2) (Bayliss et al. 2007). Of note, not all ER-negative cell lines tested re-expressed ESR1 upon MAPK inhibition. The authors observed that two basal-like cell lines did not re-express ESR1 and attributed this to hypermethylation of the ER promoter (Bayliss et al. 2007). Increased ERBB2 signalling via the PI3K/AKT pathway has also been implicated in ER suppression. Sonensheim and colleagues have observed that forced AKT activity in breast cancer cell lines can result in the inactivation of FOXO3, an ER-modulating transcription factor, and subsequent suppression of ER levels (Guo \& Sonenshein 2004). They further showed that inhibition of PI3K/AKT signalling leads to increased levels of ER expression in breast cancer cell lines (Guo \& Sonenshein 2004).

Whatever the mechanism, plasticity of tumour phenotypes indicates an opportunity for interventions that re-direct ER-negative basal tumours towards more ER-positive, luminal phenotypes and potentially the better outcomes associated with luminal tumours. Therefore, elucidating the spectrum of mechanisms by which ESR1 expression is altered, particularly those that are reversible, will illuminate tangible targets for agents to be used in combination with existing modalities that may enhance initial responsiveness and/or restore responsiveness to endocrine therapy in resistant disease.

\section{Intratumoural inflammation in breast cancer}

A growing body of evidence has revealed that the host immune system can influence tumour cell differentiation and tumour progression through the intra- or peri-tumoural inflammatory response (Reiman et al. 2007, 2010). Infiltrating leukocytes, a feature of many tumours including those of the breast, can secrete factors such as cytokines, chemokines and proteases that promote tumour angiogenesis, tissue remodelling and pro-tumourigenic signalling in both neoplastic and stromal cells (Balkwill et al. 2005). Cancers can directly sculpt inflammatory responses through the production of cytokines that influence the composition and activities of the inflammatory and immune cell compartment within the tumour (Schreiber et al. 2011).

In general terms, robust antigen-driven immune responses can drive tumour rejection and are dominated by Th1 $\mathrm{CD}^{+}$T-cells, cytotoxic $\mathrm{CD}^{+}{ }^{+} \mathrm{T}$ cells, proinflammatory M1 macrophages and Th1 cytokines such as IFN $\gamma$ (Coussens \& Werb 2002, Dunn et al. 2004; see Fig. 1). Ideally, cytotoxic killer $\mathrm{CD} 8{ }^{+} \mathrm{T}$ cells, with help from Th1 $\mathrm{CD}^{+}{ }^{+} \mathrm{T}$ cells, can recognise tumour antigens and kill cancer-cell targets via perforin and granzyme or FAS-ligandmediated pathways. Indeed, results from multiple studies have indicated that high levels of $\mathrm{CD}^{+} \mathrm{T}$ cells are associated with improved outcomes in breast cancer (Mahmoud et al. 2011, Liu et al. 2012). Th1 CD4 ${ }^{+} \mathrm{T}$ cells also polarise macrophages to an anti-tumour M1 phenotype by secreting IFN $\gamma$ (Biswas et al. 2013).

Unfortunately, tumours can adapt to such immune pressure through various mechanisms. These include exploitation of the properties of immune-derived cytokines and diversion of the immune response towards pro-tumourigenic smoldering inflammation featuring Th2 $\mathrm{CD}^{+}{ }^{+} \mathrm{T}$ cells, regulatory $\mathrm{T}$ cells (Tregs) and M2 macrophages (Balkwill et al. 2005, DeNardo \& Coussens 2007, De Palma \& Lewis 2013; Fig. 1). Th2 $\mathrm{CD}^{+}{ }^{+}$T cells secrete cytokines such as interlukin 6 (IL6) and tumour necrosis factor alpha (TNF), to promote tumour cell survival and invasion, as well as IL4 and IL13, promoting activation of M2 type macrophages (or alternatively activated macrophages). Tumour-associated macrophages

Published by Bioscientifica Ltd. 


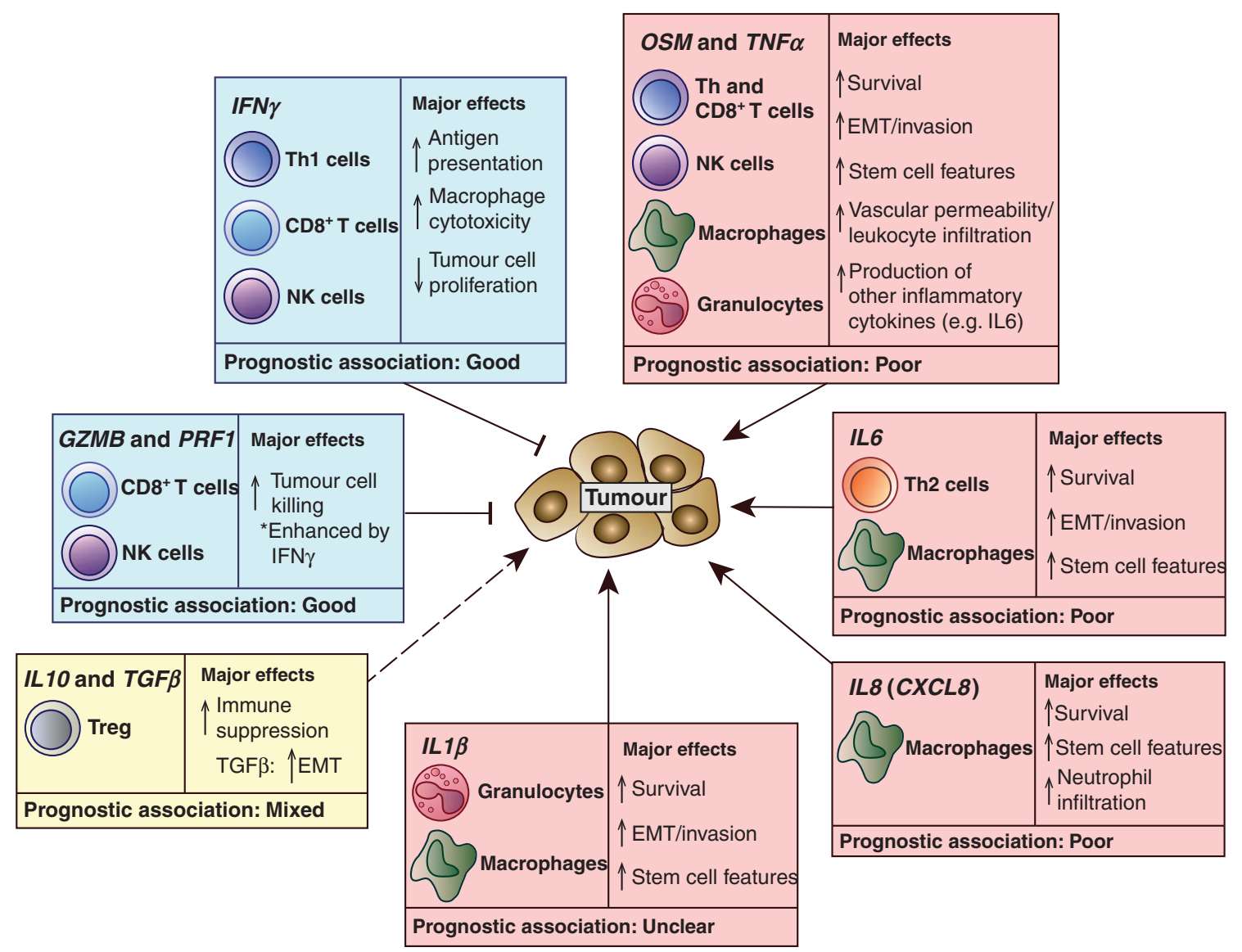

\section{Figure 1}

Cellular sources and major functions of selected cytokines in breast cancer. The breast tumour microenvironment harbours a complex milieu of immune cells and leukocyte-derived products. Shown here are common cytokines and other secreted immune factors found in breast tumours, their primary haematopoietic sources and, based on the available literature, their key tumour-modulatory effects and associations with clinical outcome. Pink represents factors that exert generally protumourigenic effects; blue, factors with host-protective roles and yellow, factors with mixed pro- and anti-tumourigenic effects. Actual effects of the indicated cytokines are likely to be highly context-dependent, with tumour molecular subtype and histological grade being particularly important

are associated with poor prognosis in breast cancer (discussed in greater detail below) and have been shown to promote pro-tumourigenic processes such as tissue remodelling, tumour angiogenesis and tumour cell invasiveness and metastasis in mouse models (Biswas et al. 2013). In a study of the complex role of the tumour microenvironment in breast cancer, DeNardo et al. (2011). found that a $\mathrm{CD} 68^{\text {high }}, \mathrm{CD} 4^{\text {high }}, \mathrm{CD} 8{ }^{\text {low }}$ phenotype (i.e. high levels of tumour-associated macrophages and $\mathrm{CD}^{+}$ $\mathrm{T}$ cells in the absence of cytotoxic $\mathrm{CD}^{+} \mathrm{T}$ cells) correlated with poor survival in breast cancer. Additional tumourassociated stromal cells, including endothelial cells, variables. Nevertheless, the balance of evidence indicates that inflammatory cytokines such as $O S M, T N F \alpha, I L 6, I L 1 \beta$ and $C X C L 8$ promote tumour progression by enhancing cancer cell survival, metastatic capacity and tumour stem cell features. In contrast, IFN $\gamma, G Z M B$ and PRF1 impair tumour progression by acting as primary effectors of cell-mediated antitumour immunity. ILIO and TGF $\beta$, produced in abundance by Tregs, have potent immune-suppressive roles and can thus impair both protective immunity and pro-tumourigenic inflammation. In addition, TGF $\beta$ can act directly on tumour cells to promote EMT. Depending on tumour phenotype, results from different studies have revealed both positive and negative associations between Tregs and clinical outcome of breast cancer.

cancer-associated fibroblasts (CAF) and adipocytes, secrete cytokines, proteases and inflammatory factors promoting tumour cell survival and tumour progression (Hanahan \& Coussens 2012, Gilbert \& Slingerland 2013). Infiltration of macrophages into breast adipose tissue results in increased prostaglandin $\left(\mathrm{PGE}_{2}\right)$ and cytokine (TNF and IL1B) signalling (Howe et al. 2013, Vona-Davis \& Rose 2013). Secreted $\mathrm{PGE}_{2}$ and TNF stimulate aromatase expression, resulting in increased estrogen levels and increased ER signalling in ER-positive breast cancer (Howe et al. 2013, Vona-Davis \& Rose 2013). Thus, the breast tumour microenvironment is rich in a variety of secreted

Published by Bioscientifica Ltd 
cytokines, chemokines and proteases that have multiple effects on tumour biology and tumour cell gene regulation, and ultimately tumour progression and response to therapy (Fig. 1). Results from gene-profiling studies have revealed inflammation-related gene clusters that predict recurrence in breast cancer patients receiving tamoxifen (Loi et al. 2008) and anastrozole (Ignatiadis et al. 2012). It is therefore important to decipher the key cytokines and cellular factors that determine the balance between beneficial and deleterious 'types' of inflammation within the tumour. Likewise, understanding the specific mechanisms whereby inflammation drives tumour progression and response to therapy is critical.

\section{Mechanisms of inflammation-mediated ER suppression}

Generally, ER-negative-status tumours have higher numbers of infiltrating leukocytes and inflammatory cytokines (Chavey et al. 2007, Teschendorff et al. 2007a). Teschendorff et al. (2007a) studied four major microarray gene expression datasets using unsupervised independent component analysis and observed a significant association between upregulation of immune response pathways (e.g. IL2RB, HLA-C, CD69, CD48,CD8A, CD19, CD14) and ER-negative status. Results from a study of cytokine expression in breast cancer have revealed high levels of multiple cytokines in breast carcinomas compared with normal breast (Chavey et al. 2007). In this study, the levels of expression of several cytokines (including IL2, IL6, IL8, IFN $\gamma$, CCL2, CCL4 and TNF) were inversely correlated with ER status and a subset (IL8, MCP1 and MIP1 $\beta$ ) correlated with leukocyte infiltration (Chavey et al. 2007). Inflammation has been shown to instigate and promote aggressive features in ER-positive breast cancer through the actions of cytokines on the interplay between ESR1 and NFאB, two key molecular switches within the breast tumour cell (recently reviewed by Baumgarten \& Frasor (2012) and Sas et al. (2012)). Activation of NFKB has been shown to cause acquired resistance and suppression of ESR1 in an MCF7 cell line model (Oida et al. 2014), and downstream of NFאB signalling, the transcriptional repressor Blimp1 has been shown to suppress transcription of ESR1 by acting directly on the ESR1 promoter (Wang et al. 2009). These examples are part of an increasing body of evidence that chronic inflammation can lead to aberrant tumour cell signalling affecting the levels or activity of ESR1. More specific support for a mechanism of inflammation-mediated modulation of ESR1 comes from more recent discoveries implicating inflammatory and leukocyte-derived cytokines (West et al. 2012) and factors (Stossi et al. 2012a, Vlaicu et al. 2013) as extracellular agents that suppress ESR1 (discussed below).

Multiple inflammatory cytokines have been implicated in suppression of ESR1 in breast cancer (Table 1). For example, TNF was shown to reduce levels of ESR1 protein in multiple breast cancer cell lines (Bhat-Nakshatri et al. 2004). Furthermore, when ESR1 was overexpressed in MDA-MB-231 cells, treatment with TNF destabilised expression of ESR1 protein in a PI3K-dependent manner (Bhat-Nakshatri et al. 2004). However, there are also conflicting reports in the literature regarding the effect of TNF. For example, TNF has been shown to increase ESR1 occupancy of the $A B C G 2$ gene and to support estrogeninduced expression of $A B C G 2$ in vitro (Pradhan et al. 2010). Similarly, TNF may support the expression of additional ER target genes such as CCND1 (Rubio et al. 2006). Both of these activities of TNF reportedly involve TNF-elicited $\mathrm{NF \kappa B}$ activation, in which NFKB cooperates with ER at the

Table1 Summary of inflammation-mediated ER suppression mechanisms

\begin{tabular}{l} 
Inflammatory factor \\
\hline Leukocyte-derived growth factors \\
(e.g. EGF) \\
Multiple growth factors and \\
cytokines (e.g. EGF, TNF, IL1 $\beta$ ) \\
activate NFKB signaling
\end{tabular}

TNF

IL6 OSM

M1 macrophage-derived factor (amphiregulin)

\section{Mechanism of ER suppression}

EGFR- and MAPK1/MAPK3 (ERK1/2) MAPK-dependent suppression of ESR1 mRNA and ER protein

$N F \kappa B$ and ER signalling crosstalk results in modulation of ER protein activity

NFKB subunit RELB-mediated activation of Blimp1 was shown to result in direct suppression of ESR1 expression PI3K-dependent ER protein destabilisation

ESR1 promoter methylation

OSMR- and MAPK1/MAPK3 (ERK1/2)

MAPK-dependent ESR1 mRNA suppression

ESR1 suppression via c-SRC, MAPK and

PKC-dependent ERK2 recruitment to ESR1 locus

\section{Reference}

Oh et al. (2001), Grant et al. (2002) and Bayliss et al. (2007)

Baumgarten \& Frasor (2012) and Sas et al. (2012)

Wang et al. (2009)

Bhat-Nakshatri et al. (2004) and Sas et al. (2012)

D'Anello et al. (2010)

Grant et al. (2002) and

West et al. (2012)

Stossi et al. $(2012 a, b)$ http://erc.endocrinology-journals.org DOI: 10.1530/ERC-14-0096
(C) 2015 Society for Endocrinology Printed in Great Britain
Published by Bioscientifica Ltd. 
level of particular ER-target gene promoters (Rubio et al. 2006, Pradhan et al. 2010).

Similarly conflicting findings have been reported for IL6, which was shown to induce methylation of the ESR1 promoter in vitro resulting in reduced levels of ER and an increase in basal-like gene expression patterns ( $\mathrm{D}^{\prime}$ Anello et al. 2010). Epigenetic regulation of ER has also been examined (Lapidus et al. 1998, Stearns et al. 2007) and may be involved in cytokine-mediated ER suppression. Nevertheless, Speirs et al. (2000) showed that IL6 activates transcription of an ERE-luciferase transgene in primary breast cancer cells in a gp130-dependent manner. Oncostatin M (OSM), discussed further below, is a member of the IL6 family and has also been shown to suppress the levels of ESR1 mRNA and protein in breast cancer cells (Grant et al. 2002). This occurs in a dose- and timedependent fashion and is dependent on the expression of the OSM receptor $\beta$ subunit, OSMR (West et al. 2012). This effect is reversible, and requires signalling by MAPK1/2 (MEK1/2) MAPKs (upstream of MAPK1/MAPK3 (ERK1/2)), with no apparent dependence on STAT3 or PI3K activity. Intriguingly, results from multiple studies of cell-extrinsic factors indicate that reversible suppression of ER by cytokines (West et al. 2012), hypoxia (Kronblad et al. 2005) and growth factor receptor signalling (Oh et al. 2001, Bayliss et al. 2007) may occur through a common mechanism involving MAPK1/MAPK3 (ERK1/2) MAPK signalling.

Beyond endocrine resistance, inflammation-mediated suppression of ER may exert significant effects on other aspects of tumour cell biology, as suppression of ER is associated with more aggressive, invasive tumours. As discussed previously, the EMT-related transcription factors Twist and Snail are associated with suppression or ER. Importantly, ER can in turn suppress another member of the Snail family, Slug; this augments expression of E-cadherin and enforces the luminal epithelial phenotype associated with ER-positive tumours (Ye et al. 2010). Similarly, ESR1 signalling impairs the expression of the NFKB subunit RELB, leading to reduced invasiveness (Wang et al. 2007). It is thus possible that inflammatory cytokines not only render breast cancers resistant to endocrine therapy via ER suppression, but also enhance pathways associated with EMT and cancer stemness as a consequence of ER loss. Indeed, IL6 and OSM can both suppress ER and induce EMT- and stem-like phenotypes in vitro (Sullivan et al. 2009, West et al. 2014). Intriguingly, while estrogen can induce expression of E-cadherin in vitro in ER-positive breast cancer cells, OSM blocks this via suppression of ER and thus promotes an overall mesenchymal/stem-like phenotype (West et al, 2014).

\section{OSM: a key driver of inflammation-mediated suppression of ER}

OSM is a member of the IL6 family of cytokines, amongst which IL6 is the prototype and has been shown to be a central factor in mediating the acute inflammatory response, the transition to chronic inflammation and the innate immune response (Naugler \& Karin 2008, Taniguchi \& Karin 2014). IL6 itself is produced relatively promiscuously by many types of stromal cells, immune cells and both normal and neoplastic epithelial cells (Royuela et al. 2004). Although IL6 is considered to promote tumour progression through several pathways (Zeisberg \& Neilson 2009), results from biomarker studies (Rincon et al. 2006, Herschkowitz et al. 2007, Anglesio et al. 2011) have not confirmed this and clinical trials of antibodies targeting IL6 or the IL6 receptor have had modest results (Garber 2009). This may be due to the complexity of differentiating between classical and transsignalling pathways or because of the broad nature of both positive and negative actions of IL6, and cellular sources makes inhibition in all cellular compartments difficult and/or leads to no net effect (Jones et al. 2011).

The closely related OSM has not been extensively studied in the context of tumours. Unlike IL6, its production appears to be largely restricted to specific inflammatory/immune cell subsets such as macrophages, T cells, neutrophils and dendritic cells (Chen \& Benveniste 2004, Queen et al. 2005, Kastl et al. 2008). OSM signals through two receptor complexes defined by OSMR or leukaemia inhibitory factor receptor (LIFR) subunits in combination with a common gp130 receptor subunit (also shared with IL6R). These receptors transduce signals through the JAK/STAT3 pathway, but MAPK and PI3K signalling events also commonly occur (Heinrich et al. 2003). Depending on the cell type, OSM has been shown to share some effects with IL6 on breast cancer cells in vitro, such as enhanced cell motility and invasion, but can exert distinct effects from IL6 in some model systems, including inhibition of proliferation and promotion of cell detachment (Jorcyk et al. 2006, Tiffen et al. 2008). Results of studies of OSM using mouse mammary tumour models have indicated that OSM contributes to increased lung and bone metastasis (Bolin et al. 2012, Guo et al. 2013). Results of analyses of human tumours to date indicate that an increase in OSM and/or OSMR occurs in relationship with tumour progression in multiple tumour types including breast and cervical cancer and that this may be associated with adverse outcome (Royuela et al. 2004, Garcia-Tunon et al. 2008, West et al. 2012, 2014, Richards 2013).

Published by Bioscientifica Ltd 
Analyses of a small cohort of human breast tumours ( $n=70$ cases) confirmed the association between OSM/OSMR signalling and reduced ER levels in vivo. High levels of expression of OSM and OSMR mRNA were detected in only $12 \%$ of ER-positive tumours compared with $45 \%$ of ER-negative tumours (West et al. 2012). Levels of OSM were significantly lower in ER-positive than in ER-negative tumours, but even within the clinically ER-positive subgroup, OSM was inversely correlated with both ESR1 and PGR levels. Further in silico analysis of mRNA expression based on a large previously published tumour dataset ( $n=321$ cases) confirmed that high levels of expression of OSM and OSMR mRNA were associated with low levels of ESR1, low expression of a set of ESR1 regulated genes, and that high levels of expression of OSMR were associated with shorter recurrence-free and overall survival in univariate and multivariate analysis (Prat et al. 2010, West et al. 2012). Intriguingly, amongst several pro-inflammatory cytokines assessed in previous studies that were shown to regulate ESR1 in vitro (including IL6 and TNF), only OSM was associated with reduced expression of ESR1-regulated genes, indicating that $O S M$ may have a unique role in the suppression of ESR1 expression (West et al. 2012). Moreover, unlike IL6 and TNF, which have been shown to augment the transcriptional activity of ESR1 in some studies, OSM not only reduces expression of ESR1 but also blocks estrogen-induced expression of progesterone receptor (West et al, 2012). This distinction between OSM and other inflammatory cytokines may in part be due to differences in their respective signal transduction mechanisms. For example, in MCF7 and T47D breast cancer cells, OSM is a more potent stimulant of MAPK signalling than IL6, correlating with its more robust effects on suppression of ER (Underhill-Day \& Heath 2006, West \& Watson 2010, West et al. 2012). This difference in MAPKinducing capacity has also been observed in other cell types such as fibroblasts and lung alveolar epithelial cells (Blanchard et al. 2001, Hintzen et al. 2009).

\section{Role of tumour-associated macrophages in cytokine-mediated suppression of ER}

Results from multiple studies support the hypothesis that macrophage-derived cytokines may be an important factor in response to chemotherapies and radiation therapies (as reviewed by De Palma \& Lewis (2013)). An additional role for tumour-associated macrophages in endocrine resistance is indicated by the inclusion of $C D 68$ as one of the 16 genes probed in the Oncotype Dx (Genomic Health) recurrence score, consistent with a role for tumour-associated macrophages in modulating response to endocrine therapy
(Kaklamani 2006, Baumgarten \& Frasor 2012). Results of clinical studies of breast cancer cohorts have indicated that tumour-associated macrophages (particularly those expressing a proliferation marker, PCNA, in addition to the general macrophage marker CD68) are associated with ER-negative status and poor prognosis in breast cancer (Campbell et al. 2011 2013). Campbell et al. (2013) probed the immune signatures of breast tumours enriched in $\mathrm{PCNA}^{+} \mathrm{CD}^{+} 8^{+}$ macrophages and observed high levels of M1-associated genes (including $T N F, I L 6$, and $I L 1 \beta$ ) compared with tumours with low levels of $\mathrm{PCNA}^{+} \mathrm{CD}^{+} 8^{+}$macrophages, indicating that proliferation of intratumoural macrophages occurs primarily in an M1 environment. M2 macrophages have also been associated with ER-negative status. A recent, large breast cancer cohort study of CD68 and CD163 (a scavenger receptor associated with M2 macrophages) has revealed that CD163 correlated with increased tumour size, grade and hormone receptor negativity (Medrek et al. 2012). The key factors associated with the recruitment of tumourassociated macrophages, such as the macrophage growth factor CSF1 and its receptor CSF1R, are also associated with high grade (Beck et al. 2009) and poor prognosis in breast cancer (Kluger et al. 2004). Furthermore, recent results have indicated that specific receptors of macrophage-secreted cytokines are associated with distinct breast cancer subtypes (Levano et al. 2011). For example, results from gene expression analyses indicated that CD44, MET, TGFBR2, $O S M R$ and EGFR were enriched in basal-like breast cancer cells when compared with luminal-like cell lines. While tumour-associated macrophages and their secreted factors are clearly implicated in progression of breast cancer, future studies are required to elucidate the complex role of tumourassociated macrophages in endocrine resistance.

Macrophage-derived cytokines and factors have been implicated in suppression of ER. Katzenellenbogen and colleagues observed that exposure of MCF7 cells to macrophage-conditioned media resulted in the suppression of ER levels via c-SRC-, MAPK- and PKC-dependent mechanisms (Stossi et al. 2012a). Briefly, THP1 macrophages were polarised to either M1 or M2 states and then the conditioned media was exposed to MCF7 cells in vitro. The effect on suppression of ER was strongest in M1polarised THP1 cells, although suppression of ER was achieved with both resting THP1 and M2-THP1 cells. Tumour-associated macrophages are a source of proinflammatory cytokines and growth factors such as EGF, TNF, IL6 and OSM (Lewis \& Pollard 2006, Biswas et al. 2013, Vlaicu et al. 2013), each of which have been implicated in suppression of ER (Table 1). Results from previous macrophage and tumour cell co-culture studies have

Published by Bioscientifica Ltd. 
indicated that macrophage-derived TNF promotes invasive properties in breast tumour cell lines (Hagemann et al. 2004 , 2005). As discussed previously, M1 type macrophage gene expression patterns have been associated with high levels of proliferating macrophages in breast tumours (Campbell et al. 2013). Furthermore, Katzenellenbogen and colleagues determined that the macrophage-stimulated hyperactivation of MAPK resulted in a novel mechanism of ER transcript repression via ERK2 recruitment to the ESR1 locus. Although the specific macrophagederived factors affecting ER regulation were not identified (Stossi et al. 2012a), results described in a subsequent abstract indicated that the unknown factor may be the EGFfamily member amphiregulin (Stossi et al. 2012b). Intriguingly, Grant et al. (2002) observed crosstalk between OSM and EGF signalling, resulting in increased ER suppression. Results from additional studies have indicated that EGF reduces ER levels in an MAPK-dependent manner (Oh et al. 2001), and that OSM and the EGF family member, heparinbinding-EGF (HBEGF), are potentially often co-secreted by tumour-associated macrophages in breast cancer (Vlaicu et al. 2013). In breast cancer, expression of OSM correlates strongly with markers of macrophages and other myeloid leukocytes, including CD14 and CD163, but correlates very weakly with lymphocyte markers (West et al. 2012). Furthermore, OSM induces expression of EGF in breast cancer cell lines, indicating an autocrine mechanism of crosstalk between OSMR and EGFR-family signalling (West \& Watson 2010). Further work is required to obtain better understanding of the specific tumour microenvironments in which pro-inflammatory cytokines and other inflammationderived factors mediate suppression of ER in breast cancer.

\section{Inflammation-induced anti-microbial peptides: potential biomarkers for cytokine action and inflammation-mediated suppression of ER}

As there are many causes of resistance to endocrine therapy, it is likely that any strategy to overcome resistance will only be beneficial in certain subsets of patients where specific mechanisms are operative. Therefore, it is important to link specific mechanisms to relevant biomarkers. Amongst the various actions that different cytokines may have on epithelial cells, induction of antimicrobial peptides that mediate aspects of the innate immune response by proinflammatory cytokines is important, not least because of the very high levels of expression observed for these proteins. These AMPs encompass several gene families including defensins and S100 proteins. While some are expressed very focally within tissues and induced more generally only under stress conditions, others are not expressed in normal tissues but are highly inducible by cytokines. The S100A7 protein is an inducible antimicrobial peptide, known to be involved in innate immunity and epithelial defense (Glaser et al. 2005, Schroder \& Harder 2006, Harder et al. 2007, Arnett \& Seveau 2011). S100A7 was originally identified in skin but was subsequently shown to be expressed in certain tumour types and stages. S100A7 is rarely expressed at high levels in normal tissues, and when present is mostly associated with hair follicles (Alowami et al. 2003, Webb et al. 2005). Induction of S100A7 is strongly associated with inflammation in skin and in tumours (Al-Haddad et al. 1999, Webb et al. 2005) and S100A7 is present at very high levels in the subsets of in situ and invasive tumours (Al-Haddad et al. 1999, Alowami et al. 2003). In fact, S100A7 has been identified in unbiased studies of mRNA and protein expression as amongst the most highly expressed genes in certain subsets of breast tumours (Leygue et al. 1996, Al-Haddad et al. 1999, Emberley et al. 2003, 2004). Some of its effects are mediated by intracellular interaction with JAB1 (Emberley et al. 2003, 2005), but S100A7 is also secreted and has chemotactic effects on inflammatory cells (Jinquan et al. 1996). Indeed, the mouse S100A7 homologue recruits tumour-associated macrophages in a murine orthotopic breast cancer model (Nasser et al. 2012). S100A7 may therefore regulate and be regulated by inflammatory processes associated with the innate immune response (Foell et al. 2007, Wolf et al. 2008, Ehrchen et al. 2009), and its high inducibility and high levels of expression are assets for any biomarker.

In common with other antimicrobial peptides, expression of S100A7 is strongly induced by pro-inflammatory cytokines in skin (Di Nuzzo et al. 2000, Wolk et al. 2006, Simanski et al. 2013) and can also be regulated by ESR2 (Skliris et al. 2007). Accordingly, S100A7 is well recognised as a marker of skin inflammation in conditions such as psoriasis. In breast cancer, OSM not only suppresses ER but is also a strong inducer of S100A7 in both ER-positive (MCF7 and T47D) and ER-negative (MDA-MB-468) breast cancer cell lines (West \& Watson 2010). Although other pro-inflammatory cytokines can also induce S100A7 to some degree, several of these are most effective in synergy with OSM (West \& Watson 2010). Analysis of human breast tumours has confirmed that OSM and OSMR are significantly associated with expression of S100A7. Furthermore, S100A7 only correlates with poor outcome in those tumours with high levels of expression of OSMR (West \& Watson 2010). Therefore, S100A7 has the potential to be a tumour cell biomarker of OSM-mediated suppression of ER

Published by Bioscientifica Ltd. 
and draws attention to the potential role of other antimicrobial peptides as biomarkers.

\section{Potential for targeted therapy to restore expression of ESR1 and anti-estrogen sensitivity}

Targeting tumour inflammation could allow the reversal of suppression of ER and restoration of sensitivity to endocrine therapy. However, a complex relationship between inflammatory cells and endocrine therapy may exist and must be studied in greater detail. For example, anti-estrogen efficacy may be modulated by the tumour microenvironment. Results from preclinical studies indicated that NK cells play a role in the anti-tumour effects of tamoxifen via a TGFB2-dependent mechanism (Arteaga et al. 1999). Recent preclinical studies by Clarke and colleagues studying the ability of the autophagy inhibitor hydroxychloroquine (HQC) to target endocrineresistant xenografts have suggested that tamoxifen and fulvestrant differentially modulate the functioning of macrophages in the breast tumour microenvironment (Cook et al. 2014). The combination of HQC and tamoxifen increased the anti-estrogen responsiveness and also led to an increase in peripheral infiltration of macrophages, while the combination of HQC and fulvestrant led to reduced anti-estrogen responsiveness and decreased peripheral infiltration of macrophages. The authors also observed that fulvestrant treatment alone reduced the killing ability of macrophage cells in vitro and reduced peripheral infiltration of macrophages in vivo. The results of these studies indicate that targeting inflammation may have an important role in the prevention of endocrine resistance in ER-positive breast cancer and underscore that macrophages may have multiple roles in breast cancer.

A growing body of data supports a model where suppression of ER can play a key role during inflammationmediated tumour progression in breast cancer patients. This potentially opens a new avenue for improved therapy. Results from epidemiological studies have revealed an association of NSAID use with reduced risk and severity of breast cancer (Kwan et al. 2007, Holmes et al. 2010), and increased levels of PTGS2 (COX2) in breast cancer have been associated with increased risk of breast cancer and a poorer prognosis (Fornetti et al. 2014). Blockade of inflammation in breast tumours may reverse the suppression of ESR1 expression in ER-positive tumours with low levels of ESR1 or tumours that are clinically ER-negative. This in turn could enhance clinical responses to endocrine therapy (Schiff \& Osborne 2005, Billam et al. 2009, Brinkman \& El-Ashry 2009). It is well established that response to endocrine therapies is closely related levels of ER.
In ER-positive cell lines, culture conditions that promote higher levels of expression of ER result in improved response to estradiol $\left(\mathrm{E}_{2}\right)$ and effectiveness of inhibition by SERMs (Sabnis et al. 2011). In ESR1-negative tumours, induction of ER has not been attempted in vivo. But in some ESR1-negative cell lines, re-expression of ESR1 can result in inhibition of growth, restore a functional ER pathway and re-establish responsiveness to tamoxifen (Bayliss et al. 2007). A potential explanation for these observations lies in the complex role of the second ER, ESR2 which is not currently considered in the clinical assignment of ER status. In tumour cell line studies, both ESR1 and ESR2 bind $\mathrm{E}_{2}$, but ESR2 is thought to mostly oppose the action of ESR1 and is typically anti-proliferative when overexpressed in ESR1-positive cells (Murphy et al. 2005). Expression of ESR2 in ESR1-expressing cells also confers enhanced responses to tamoxifen (Murphy \& Watson 2006, Hartman et al. 2009). Results from recent studies have indicated that these conclusions, which are based predominantly on results from studies of transient expression, may need re-examination (Jonsson et al. 2014). However, consistent with these laboratory observations, an overall positive association between ESR2 expression and good clinical outcome in ESR1-positive tumours has been described (Murphy \& Watson 2006, Hartman et al. 2009, Motomura et al. 2010). However, the effects of ESR2 in ESR1negative tumours may be different. There are two subgroups of clinically ER-negative tumours; ESR1-negative/ESR2positive (approximately two-thirds of clinically ER-negative tumours) and ESR1 negative/ESR2-negative (approximately one-third of ER-negative tumours). In the former subgroup of clinically ER-negative tumours, ESR2 expression unopposed by ESR1 correlates positively with the proliferation marker Ki67 and may confer a worse prognosis (Younes \& Honma 2011, Murphy \& Leygue 2012). Although largely untested in clinical settings, results from, some recent studies have indicated that these ESR1-negative/ESR2-positive tumours may also be responsive to tamoxifen (Yan et al. 2013). Therefore, it seems possible that restoration of expression of ESR1 in ESR1-negative/ESR2-positive tumours in vivo may act to either disrupt the pro-proliferative effect of ESR2 or re-engage estrogen-responsive gene pathways, and so may conceivably restore effectiveness of endocrine therapy (Yan et al. 2013). In the future, established assays for ESR2 (Skliris et al. 2006, Weitsman et al. 2006) and markers for the action of ESR2 (Skliris et al. 2007) may prove useful in discriminating the biology of ESR1-negative/ESR2-positive tumours in conjunction with progress in the generation of ESR2-specific agents.

While the patterns of intratumoural inflammation can be variable and exert profound positive and negative

Published by Bioscientifica Ltd 


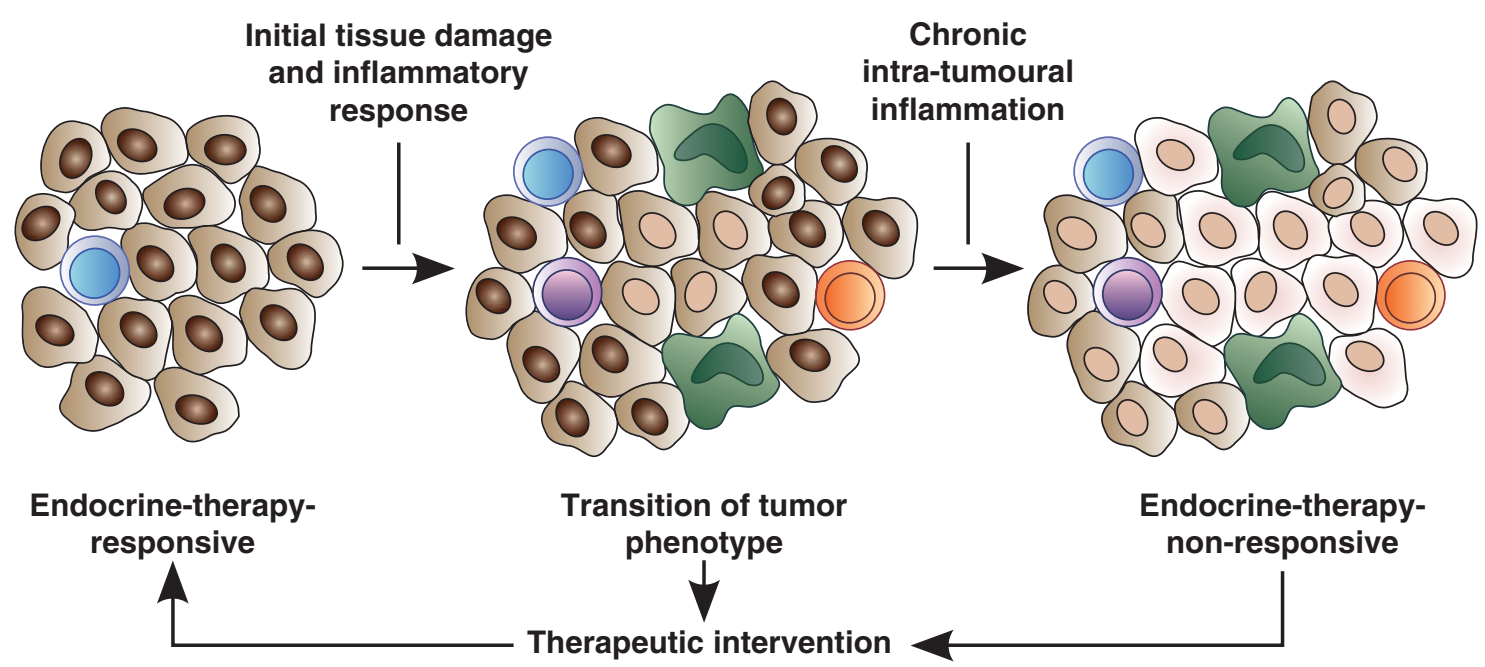

LEGEND:
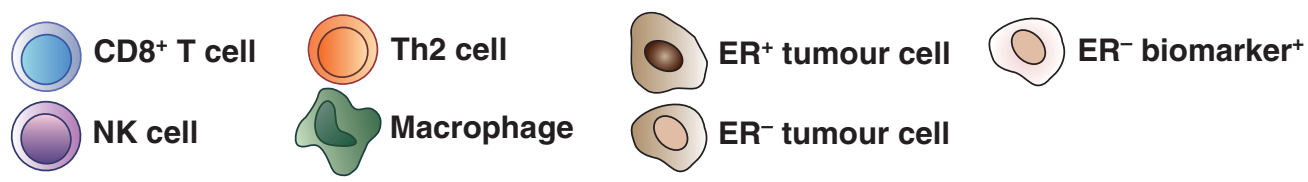

Figure 2

Model depicting inflammation-mediated ER suppression. Macrophage infiltration during chronic inflammation results in macrophage-derived factors signalling to tumour cells and suppression of ER levels. The tumour ultimately becomes unresponsive to endocrine therapy and potentially

effects on behaviour of cancer in different contexts, it is important to recognise that the cells responsible for this inflammation are genetically normal. Inflammatory cells do not share the ability of the cancer cell population to evolve with new mutations to circumvent therapies, thus offering a potentially more stable target. Inflammation has been the focus of extensive and successful drug development, from aspirin to newer antibody-based therapies to revolutionise treatment of chronic inflammatory conditions (Scott 2012). The association between inflammation-derived cytokines and tumour progression has led to the development of targeted anti-inflammatory therapeutics including NFKB signalling inhibitors, TNF/TNFR antagonists and IL6 antagonists (Goldberg \& Schwertfeger 2010, Balkwill \& Mantovani 2012, Coussens et al. 2013). Targeting tumour inflammation is thus a promising and increasingly recognised approach for providing personalised therapy to cancer patients.

\section{Summary}

Specific mechanisms are emerging to explain how the immune system and the intratumoural inflammatory more aggressive. Identification of biomarkers of this macrophage-tumour cell interaction could identify patients that would benefit from targeted anti-inflammatory agents.

response can directly affect the level of ESR1 in breast cancer. It remains to be proven that these mechanisms are operative in patients. OSM and possibly other synergistic inflammation-derived cytokines can cause suppression of ESR1 in vitro and are correlated with reduced expression of ESR1 in vivo (West et al. 2012). Strategies targeting intratumoural inflammation to remove the suppression of ESR1 may therefore be effective in enhancing endocrine therapy (Fig. 2). However, these strategies are likely to be beneficial only in certain tumours where intratumoural inflammation is present and cytokine-mediated suppression of ESR1 is in evidence. Additional biomarkers are required to identify breast cancer patients who would benefit from antiinflammatory treatment (Fig. 2). S100A7, as a functional component of the action of OSM, represents a possible biomarker for this potentially important clinical effect within both ER-positive and ER-negative breast tumours. The notion that inflammation-induced peptides may provide specific biomarkers for this aspect of cytokine activity raises the possibility that this phenomenon can be identified in clinical settings, and that specific therapies targeting cytokine pathways or cytokine-producing cells may be deployed to improve the response to endocrine therapy.

Published by Bioscientifica Ltd. 


\section{Declaration of interest}

The authors declare that there is no conflict of interest that could be perceived as prejudicing the impartiality of this review.

\section{Author contribution statement}

JI Murray, N R West, L C Murphy and P H Watson contributed to writing the manuscript.

\section{Funding}

This work is supported by the Canadian Breast Cancer Foundation $\mathrm{BC} /$ Yukon Region ( $\mathrm{P} \mathrm{H}$ Watson), BC Cancer Foundation ( $\mathrm{P} \mathrm{H}$ Watson), the Canadian Institutes of Health Research ( $L$ C Murphy), the Canadian Breast Cancer Foundation Prairies/NWT Region (L C Murphy) and the Canadian Cancer Society Research Institute (L C Murphy). J I Murray is supported by a Canadian Breast Cancer Foundation BC/Yukon Region postdoctoral fellowship. N R West is supported by the Irvington Institute Fellowship Program of the Cancer Research Institute. This study was also supported by the Manitoba Breast Tumour Bank, funded in part by the CancerCare Manitoba Foundation and Canadian Institutes of Health Research, and the BC Cancer Agency Tumor Tissue Repository, funded in part by the BC Cancer Foundation, both member banks of the Canadian Tumour Repository Network.

\section{References}

Al-Haddad S, Zhang Z, Leygue E, Snell L, Huang A, Niu Y, Hiller-Hitchcock T, Hole K, Murphy LC \& Watson PH 1999 Psoriasin (S100A7) expression and invasive breast cancer. American Journal of Pathology 155 2057-2066. (doi:10.1016/S0002-9440(10)65524-1)

Alowami S, Qing G, Emberley E, Snell L \& Watson PH 2003 Psoriasin (S100A7) expression is altered during skin tumorigenesis. BMC Dermatology 3 1. (doi:10.1186/1471-5945-3-1)

Andre F, Dieci MV, Dubsky P, Sotiriou C, Curigliano G, Denkert C \& Loi S 2013 Molecular pathways: involvement of immune pathways in the therapeutic response and outcome in breast cancer. Clinical Cancer Research 19 28-33. (doi:10.1158/1078-0432.CCR-11-2701)

Anglesio MS, George J, Kulbe H, Friedlander M, Rischin D, Lemech C, Power J, Coward J, Cowin PA, House CM et al. 2011 IL6-STAT3-HIF signaling and therapeutic response to the angiogenesis inhibitor sunitinib in ovarian clear cell cancer. Clinical Cancer Research 17 2538-2548. (doi:10.1158/1078-0432.CCR-10-3314)

Antoon JW, Bratton MR, Guillot LM, Wadsworth S, Salvo VA \& Burow ME 2012 Inhibition of p38-MAPK alters SRC coactivation and estrogen receptor phosphorylation. Cancer Biology \& Therapy 13 1026-1033. (doi:10.4161/cbt.20992)

Antoon JW, Martin EC, Lai R, Salvo VA, Tang Y, Nitzchke AM, Elliott S, Nam SY, Xiong W, Rhodes LV et al. 2013 MEK5/ERK5 signaling suppresses estrogen receptor expression and promotes hormoneindependent tumorigenesis. PLOS ONE 8 e69291. (doi:10.1371/journal. pone.0069291)

Arnett E \& Seveau S 2011 The multifaceted activities of mammalian defensins. Current Pharmaceutical Design 17 4254-4269. (doi:10.2174/ 138161211798999348)

Arpino G, Wiechmann L, Osborne CK \& Schiff R 2008 Crosstalk between the estrogen receptor and the HER tyrosine kinase receptor family: molecular mechanism and clinical implications for endocrine therapy resistance. Endocrine Reviews 29 217-233. (doi:10.1210/er.2006-0045)

Arteaga CL, Koli KM, Dugger TC \& Clarke R 1999 Reversal of tamoxifen resistance of human breast carcinomas in vivo by neutralizing antibodies to transforming growth factor- $\beta$. Journal of the National Cancer Institute 91 46-53. (doi:10.1093/jnci/91.1.46)

Balkwill FR \& Mantovani A 2012 Cancer-related inflammation: common themes and therapeutic opportunities. Seminars in Cancer Biology 22 33-40. (doi:10.1016/j.semcancer.2011.12.005)

Balkwill F, Charles KA \& Mantovani A 2005 Smoldering and polarized inflammation in the initiation and promotion of malignant disease. Cancer Cell 7 211-217. (doi:10.1016/j.ccr.2005.02.013)

Baumgarten SC \& Frasor J 2012 Minireview: Inflammation: an instigator of more aggressive estrogen receptor (ER) positive breast cancers. Molecular Endocrinology 26 360-371. (doi:10.1210/me.2011-1302)

Bayliss J, Hilger A, Vishnu P, Diehl K \& El-Ashry D 2007 Reversal of the estrogen receptor negative phenotype in breast cancer and restoration of antiestrogen response. Clinical Cancer Research 13 7029-7036. (doi:10.1158/1078-0432.CCR-07-0587)

Beck AH, Espinosa I, Edris B, Li R, Montgomery K, Zhu S, Varma S, Marinelli RJ, van de Rijn M \& West RB 2009 The macrophage colonystimulating factor 1 response signature in breast carcinoma. Clinical Cancer Research 15 778-787. (doi:10.1158/1078-0432.CCR-08-1283)

Bernardo GM, Lozada KL, Miedler JD, Harburg G, Hewitt SC, Mosley JD, Godwin AK, Korach KS, Visvader JE, Kaestner KH et al. 2010 FOXA1 is an essential determinant of $\mathrm{ER} \alpha$ expression and mammary ductal morphogenesis. Development 137 2045-2054. (doi:10.1242/dev.043299)

Bernardo GM, Bebek G, Ginther CL, Sizemore ST, Lozada KL, Miedler JD, Anderson LA, Godwin AK, Abdul-Karim FW, Slamon DJ et al. 2013 FOXA1 represses the molecular phenotype of basal breast cancer cells. Oncogene 32 554-563. (doi:10.1038/onc.2012.62)

Bertucci F, Finetti P \& Birnbaum D 2012 Basal breast cancer: a complex and deadly molecular subtype. Current Molecular Medicine 12 96-110. (doi:10.2174/156652412798376134)

Bhat-Nakshatri P, Campbell RA, Patel NM, Newton TR, King AJ, Marshall MS, Ali S \& Nakshatri H 2004 Tumour necrosis factor and PI3-kinase control oestrogen receptor alpha protein level and its transrepression function. British Journal of Cancer 90 853-859. (doi:10.1038/sj.bjc.6601541)

Billam M, Witt AE \& Davidson NE 2009 The silent estrogen receptor - can we make it speak? Cancer Biology \& Therapy 8 485-496. (doi:10.4161/ cbt.8.6.7582)

Biswas SK, Allavena P \& Mantovani A 2013 Tumor-associated macrophages: functional diversity, clinical significance, and open questions. Seminars in Immunopathology 35 585-600. (doi:10.1007/s00281-013-0367-7)

Blanchard F, Wang Y, Kinzie E, Duplomb L, Godard A \& Baumann H 2001 Oncostatin $M$ regulates the synthesis and turnover of gp130, leukemia inhibitory factor receptor $\alpha$, and oncostatin M receptor $\beta$ by distinct mechanisms. Journal of Biological Chemistry 276 47038-47045. (doi:10.1074/jbc.M107971200)

Bolin C, Tawara K, Sutherland C, Redshaw J, Aranda P, Moselhy J, Anderson R \& Jorcyk CL 2012 Oncostatin m promotes mammary tumor metastasis to bone and osteolytic bone degradation. Genes \& Cancer 3 117-130. (doi:10.1177/1947601912458284)

Brinkman JA \& El-Ashry D 2009 ER re-expression and re-sensitization to endocrine therapies in ER-negative breast cancers. Journal of Mammary Gland Biology and Neoplasia 14 67-78. (doi:10.1007/s10911-009-9113-0)

Brodie A, Jelovac D, Macedo L, Sabnis G, Tilghman S \& Goloubeva O 2005 Therapeutic observations in MCF-7 aromatase xenografts. Clinical Cancer Research 11 884s-888s.

Broom RJ, Tang PA, Simmons C, Bordeleau L, Mulligan AM, O'Malley FP, Miller N, Andrulis IL, Brenner DM \& Clemons MJ 2009 Changes in estrogen receptor, progesterone receptor and Her-2/neu status with time: discordance rates between primary and metastatic breast cancer. Anticancer Research 29 1557-1562.

Bunone G, Briand PA, Miksicek RJ \& Picard D 1996 Activation of the unliganded estrogen receptor by EGF involves the MAP kinase pathway and direct phosphorylation. EMBO Journal 15 2174-2183.

Campbell MJ, Tonlaar NY, Garwood ER, Huo D, Moore DH, Khramtsov AI, Au A, Baehner F, Chen Y, Malaka DO et al. 2011 Proliferating macrophages associated with high grade, hormone receptor negative 
breast cancer and poor clinical outcome. Breast Cancer Research and Treatment 128 703-711. (doi:10.1007/s10549-010-1154-y)

Campbell MJ, Wolf D, Mukhtar RA, Tandon V, Yau C, Au A, Baehner F, van't Veer L, Berry D \& Esserman LJ 2013 The prognostic implications of macrophages expressing proliferating cell nuclear antigen in breast cancer depend on immune context. PLOS ONE 8 e79114. (doi:10.1371/ journal.pone.0079114)

Chavey C, Bibeau F, Gourgou-Bourgade S, Burlinchon S, Boissiere F, Laune D, Roques S \& Lazennec G 2007 Oestrogen receptor negative breast cancers exhibit high cytokine content. Breast Cancer Research 9 R15. (doi:10.1186/bcr1648)

Cheang MC, Voduc D, Bajdik C, Leung S, McKinney S, Chia SK, Perou CM \& Nielsen TO 2008 Basal-like breast cancer defined by five biomarkers has superior prognostic value than triple-negative phenotype. Clinical Cancer Research 14 1368-1376. (doi:10.1158/1078-0432.CCR-07-1658)

Chen SH \& Benveniste EN 2004 Oncostatin M: a pleiotropic cytokine in the central nervous system. Cytokine \& Growth Factor Reviews 15 379-391. (doi:10.1016/j.cytogfr.2004.06.002)

Cook KL, Warri A, Soto-Pantoja DR, Clarke PA, Cruz MI, Zwart A \& Clarke R 2014 Hydroxychloroquine inhibits autophagy to potentiate antiestrogen responsiveness in $\mathrm{ER}^{+}$breast cancer. Clinical Cancer Research 20 3222-3232. (doi:10.1158/1078-0432.CCR-13-3227)

Coussens LM \& Werb Z 2002 Inflammation and cancer. Nature 420 860-867. (doi:10.1038/nature01322)

Coussens LM, Zitvogel L \& Palucka AK 2013 Neutralizing tumorpromoting chronic inflammation: a magic bullet? Science 339 286-291. (doi:10.1126/science.1232227)

Creighton CJ, Hilger AM, Murthy S, Rae JM, Chinnaiyan AM \& El-Ashry D 2006 Activation of mitogen-activated protein kinase in estrogen receptor $\alpha$-positive breast cancer cells in vitro induces an in vivo molecular phenotype of estrogen receptor $\alpha$-negative human breast tumors. Cancer Research 66 3903-3911. (doi:10.1158/0008-5472.CAN-05-4363)

Creighton CJ, Fu X, Hennessy BT, Casa AJ, Zhang Y, Gonzalez-Angulo AM, Lluch A, Gray JW, Brown PH, Hilsenbeck SG et al. 2010 Proteomic and transcriptomic profiling reveals a link between the PI3K pathway and lower estrogen-receptor (ER) levels and activity in ER+ breast cancer. Breast Cancer Research 12 R40. (doi:10.1186/bcr2594)

Cui X, Zhang P, Deng W, Oesterreich S, Lu Y, Mills GB \& Lee AV 2003 Insulinlike growth factor-I inhibits progesterone receptor expression in breast cancer cells via the phosphatidylinositol 3-kinase/Akt/mammalian target of rapamycin pathway: progesterone receptor as a potential indicator of growth factor activity in breast cancer. Molecular Endocrinology 17 575-588. (doi:10.1210/me.2002-0318)

Cui X, Schiff R, Arpino G, Osborne CK \& Lee AV 2005 Biology of progesterone receptor loss in breast cancer and its implications for endocrine therapy. Journal of Clinical Oncology 23 7721-7735. (doi:10.1200/JCO.2005.09.004)

Curtis C, Shah SP, Chin SF, Turashvili G, Rueda OM, Dunning MJ, Speed D, Lynch AG, Samarajiwa S, Yuan Y et al. 2012 The genomic and transcriptomic architecture of 2,000 breast tumours reveals novel subgroups. Nature 486 346-352. (doi:10.1038/nature10983)

D'Anello L, Sansone P, Storci G, Mitrugno V, D'Uva G, Chieco P \& Bonafe M 2010 Epigenetic control of the basal-like gene expression profile via interleukin-6 in breast cancer cells. Molecular Cancer 9300 . (doi:10.1186/ 1476-4598-9-300)

DeNardo DG \& Coussens LM 2007 Inflammation and breast cancer. Balancing immune response: crosstalk between adaptive and innate immune cells during breast cancer progression. Breast Cancer Research 9 212. (doi:10.1186/bcr1746)

DeNardo DG, Brennan DJ, Rexhepaj E, Ruffell B, Shiao SL, Madden SF, Gallagher WM, Wadhwani N, Keil SD, Junaid SA et al. 2011 Leukocyte complexity predicts breast cancer survival and functionally regulates response to chemotherapy. Cancer Discovery 1 54-67. (doi:10.1158/ 2159-8274.CD-10-0028)

De Palma M \& Lewis CE 2013 Macrophage regulation of tumor responses to anticancer therapies. Cancer Cell 23 277-286. (doi:10.1016/j.ccr. 2013.02.013)
Desmedt C, Haibe-Kains B, Wirapati P, Buyse M, Larsimont D, Bontempi G, Delorenzi M, Piccart M \& Sotiriou C 2008 Biological processes associated with breast cancer clinical outcome depend on the molecular subtypes. Clinical Cancer Research 14 5158-5165. (doi:10.1158/1078-0432.CCR-07-4756)

Dhasarathy A, Kajita M \& Wade PA 2007 The transcription factor snail mediates epithelial to mesenchymal transitions by repression of estrogen receptor- $\alpha$. Molecular Endocrinology 21 2907-2918. (doi:10.1210/me.2007-0293)

Di Nuzzo S, Sylva-Steenland RM, Koomen CW, de Rie MA, Das PK, Bos JD \& Teunissen MB 2000 Exposure to UVB induces accumulation of LFA-1 ${ }^{+}$ $\mathrm{T}$ cells and enhanced expression of the chemokine psoriasin in normal human skin. Photochemistry and Photobiology 72 374-382. (doi:10.1562/ 0031-8655(2000)0720374ETUIAO2.0.CO2)

Doane AS, Danso M, Lal P, Donaton M, Zhang L, Hudis C \& Gerald WL 2006 An estrogen receptor-negative breast cancer subset characterized by a hormonally regulated transcriptional program and response to androgen. Oncogene 25 3994-4008. (doi:10.1038/sj.onc.1209415)

Dunn GP, Old LJ \& Schreiber RD 2004 The three Es of cancer immunoediting. Annual Review of Immunology 22 329-360. (doi:10.1146/annurev.immunol.22.012703.104803)

Early Breast Cancer Trialists' Collaborative Group (EBCTCG) 2005 Effects of chemotherapy and hormonal therapy for early breast cancer on recurrence and 15-year survival: an overview of the randomised trials. Lancet 365 1687-1717. (doi:10.1016/S0140-6736(05)66544-0)

Ehrchen JM, Sunderkotter C, Foell D, Vogl T \& Roth J 2009 The endogenous Toll-like receptor 4 agonist S100A8/S100A9 (calprotectin) as innate amplifier of infection, autoimmunity, and cancer. Journal of Leukocyte Biology 86 557-566. (doi:10.1189/jlb.1008647)

Ellis MJ, Ding L, Shen D, Luo J, Suman VJ, Wallis JW, Van Tine BA, Hoog J, Goiffon RJ, Goldstein TC et al. 2012 Whole-genome analysis informs breast cancer response to aromatase inhibition. Nature 486 353-360. (doi:10.1038/nature11143)

Emberley ED, Niu Y, Leygue E, Tomes L, Gietz RD, Murphy LC \& Watson PH 2003 Psoriasin interacts with Jab1 and influences breast cancer progression. Cancer Research 63 1954-1961.

Emberley ED, Alowami S, Snell L, Murphy LC \& Watson PH 2004 S100A7 (psoriasin) expression is associated with aggressive features and alteration of Jab1 in ductal carcinoma in situ of the breast. Breast Cancer Research 6 R308-R315. (doi:10.1186/bcr791)

Emberley ED, Niu Y, Curtis L, Troup S, Mandal SK, Myers JN, Gibson SB, Murphy LC \& Watson PH 2005 The S100A7-c-Jun activation domain binding protein 1 pathway enhances prosurvival pathways in breast cancer. Cancer Research 65 5696-5702. (doi:10.1158/0008-5472.CAN04-3927)

Faridi J, Wang L, Endemann G \& Roth RA 2003 Expression of constitutively active Akt-3 in MCF-7 breast cancer cells reverses the estrogen and tamoxifen responsivity of these cells in vivo. Clinical Cancer Research 9 2933-2939.

Foell D, Wittkowski H, Vogl T \& Roth J 2007 S100 proteins expressed in phagocytes: a novel group of damage-associated molecular pattern molecules. Journal of Leukocyte Biology 81 28-37. (doi:10.1189/jlb.0306170)

Fornetti J, Jindal S, Middleton KA, Borges VF \& Schedin P 2014 Physiological COX-2 expression in breast epithelium associates with COX-2 levels in ductal carcinoma in situ and invasive breast cancer in young women. American Journal of Pathology 184 1219-1229. (doi:10.1016/j.ajpath.2013.12.026)

Frend HT \& Watson CJ 2013 Elf5 - breast cancer's little helper. Breast Cancer Research 15 307. (doi:10.1186/bcr3397)

Garber K 2009 First results for agents targeting cancer-related inflammation. Journal of the National Cancer Institute 101 1110-1112. (doi:10.1093/jnci/djp266)

Garcia-Tunon I, Ricote M, Ruiz A, Fraile B, Paniagua R \& Royuela M 2008 OSM, LIF, its receptors, and its relationship with the malignance in human breast carcinoma (in situ and in infiltrative). Cancer Investigation 26 222-229. (doi:10.1080/07357900701638491) 
Gee JM, Howell A, Gullick WJ, Benz CC, Sutherland RL, Santen RJ, Martin LA, Ciardiello F, Miller WR, Dowsett M et al. 2005 Consensus statement. Workshop on therapeutic resistance in breast cancer: impact of growth factor signalling pathways and implications for future treatment. Endocrine-Related Cancer 12 (Suppl 1) S1-S7. (doi:10.1677/erc.1.01054)

Giamas G, Filipovic A, Jacob J, Messier W, Zhang H, Yang D, Zhang W, Shifa BA, Photiou A, Tralau-Stewart C et al. 2011 Kinome screening for regulators of the estrogen receptor identifies LMTK3 as a new therapeutic target in breast cancer. Nature Medicine 17 715-719. (doi:10.1038/nm.2351)

Gilbert CA \& Slingerland JM 2013 Cytokines, obesity, and cancer: new insights on mechanisms linking obesity to cancer risk and progression. Annual Review of Medicine 64 45-57. (doi:10.1146/annurev-med121211-091527)

Glaser R, Harder J, Lange H, Bartels J, Christophers E \& Schroder JM 2005 Antimicrobial psoriasin (S100A7) protects human skin from Escherichia coli infection. Nature Immunology 6 57-64. (doi:10.1038/ni1142)

Goldberg JE \& Schwertfeger KL 2010 Proinflammatory cytokines in breast cancer: mechanisms of action and potential targets for therapeutics. Current Drug Targets 11 1133-1146. (doi:10.2174/ 138945010792006799)

Goldhirsch A, Ingle JN, Gelber RD, Coates AS, Thurlimann B, Senn HJ \& Panel M 2009 Thresholds for therapies: highlights of the St Gallen International Expert Consensus on the primary therapy of early breast cancer 2009. Annals of Oncology 20 1319-1329. (doi:10.1093/annonc/ mdp322)

deGraffenried LA, Chandrasekar B, Friedrichs WE, Donzis E, Silva J, Hidalgo M, Freeman JW \& Weiss GR 2004 NF-к B inhibition markedly enhances sensitivity of resistant breast cancer tumor cells to tamoxifen. Annals of Oncology 15 885-890. (doi:10.1093/annonc/mdh232)

Grant SL, Hammacher A, Douglas AM, Goss GA, Mansfield RK, Heath JK \& Begley CG 2002 An unexpected biochemical and functional interaction between gp130 and the EGF receptor family in breast cancer cells. Oncogene 21 460-474. (doi:10.1038/sj.onc.1205100)

Guo S \& Sonenshein GE 2004 Forkhead box transcription factor FOXO3a regulates estrogen receptor alpha expression and is repressed by the Her-2/neu/phosphatidylinositol 3-kinase/Akt signaling pathway. Molecular and Cellular Biology 24 8681-8690. (doi:10.1128/MCB.24.19. 8681-8690.2004)

Guo L, Chen C, Shi M, Wang F, Chen X, Diao D, Hu M, Yu M, Qian L \& Guo N 2013 Stat3-coordinated Lin-28-let-7-HMGA2 and miR-200-ZEB1 circuits initiate and maintain oncostatin M-driven epithelial-mesenchymal transition. Oncogene 32 5272-5282. (doi:10.1038/onc.2012.573)

Gutierrez MC, Detre S, Johnston S, Mohsin SK, Shou J, Allred DC, Schiff R, Osborne CK \& Dowsett M 2005 Molecular changes in tamoxifenresistant breast cancer: relationship between estrogen receptor, HER-2, and p38 mitogen-activated protein kinase. Journal of Clinical Oncology 23 2469-2476. (doi:10.1200/JCO.2005.01.172)

Guttilla IK, Adams BD \& White BA 2012 ER $\alpha$, microRNAs, and the epithelial-mesenchymal transition in breast cancer. Trends in Endocrinology and Metabolism 23 73-82. (doi:10.1016/j.tem.2011.12.001)

Hagemann T, Robinson SC, Schulz M, Trumper L, Balkwill FR \& Binder C 2004 Enhanced invasiveness of breast cancer cell lines upon co-cultivation with macrophages is due to TNF- $\alpha$ dependent up-regulation of matrix metalloproteases. Carcinogenesis 25 1543-1549. (doi:10.1093/carcin/bgh146)

Hagemann T, Wilson J, Kulbe H, Li NF, Leinster DA, Charles K, Klemm F, Pukrop T, Binder C \& Balkwill FR 2005 Macrophages induce invasiveness of epithelial cancer cells via NF- $\mathrm{B}$ and JNK. Journal of Immunology 175 1197-1205. (doi:10.4049/jimmunol.175.2.1197)

Hammond ME, Hayes DF, Dowsett M, Allred DC, Hagerty KL, Badve S, Fitzgibbons PL, Francis G, Goldstein NS, Hayes M et al. 2010 American Society of Clinical Oncology/College of American Pathologists guideline recommendations for immunohistochemical testing of estrogen and progesterone receptors in breast cancer. Journal of Clinical Oncology 28 2784-2795. (doi:10.1200/JCO.2009.25.6529)
Hanahan D \& Coussens LM 2012 Accessories to the crime: functions of cells recruited to the tumor microenvironment. Cancer Cell 21 309-322. (doi:10.1016/j.ccr.2012.02.022)

Hanahan D \& Weinberg RA 2011 Hallmarks of cancer: the next generation. Cell 144 646-674. (doi:10.1016/j.cell.2011.02.013)

Harder J, Glaser R \& Schroder JM 2007 Human antimicrobial proteins effectors of innate immunity. Journal of Endotoxin Research 13 317-338. (doi:10.1177/0968051907088275)

Hartman J, Strom A \& Gustafsson JA 2009 Estrogen receptor beta in breast cancer - diagnostic and therapeutic implications. Steroids 74 635-641. (doi:10.1016/j.steroids.2009.02.005)

Haughian JM, Pinto MP, Harrell JC, Bliesner BS, Joensuu KM, Dye WW, Sartorius CA, Tan AC, Heikkila P, Perou CM et al. 2012 Maintenance of hormone responsiveness in luminal breast cancers by suppression of Notch. PNAS 109 2742-2747. (doi:10.1073/pnas.1106509108)

Heinrich PC, Behrmann I, Haan S, Hermanns HM, Muller-Newen G \& Schaper F 2003 Principles of interleukin (IL)-6-type cytokine signalling and its regulation. Biochemical Journal 374 1-20. (doi:10.1042/ BJ20030407)

Herschkowitz JI, Simin K, Weigman VJ, Mikaelian I, Usary J, Hu Z, Rasmussen KE, Jones LP, Assefnia S, Chandrasekharan S et al. 2007 Identification of conserved gene expression features between murine mammary carcinoma models and human breast tumors. Genome Biology 8 R76. (doi:10.1186/gb-2007-8-5-r76)

Hintzen C, Quaiser S, Pap T, Heinrich PC \& Hermanns HM 2009 Induction of CCL13 expression in synovial fibroblasts highlights a significant role of oncostatin M in rheumatoid arthritis. Arthritis and Rheumatism 60 1932-1943. (doi:10.1002/art.24602)

Holmes MD, Chen WY, Li L, Hertzmark E, Spiegelman D \& Hankinson SE 2010 Aspirin intake and survival after breast cancer. Journal of Clinical Oncology 28 1467-1472. (doi:10.1200/JCO.2009.22.7918)

Howe LR, Subbaramaiah K, Hudis CA \& Dannenberg AJ 2013 Molecular pathways: adipose inflammation as a mediator of obesity-associated cancer. Clinical Cancer Research 19 6074-6083. (doi:10.1158/10780432.CCR-12-2603)

Ignatiadis M, Singhal SK, Desmedt C, Haibe-Kains B, Criscitiello C, Andre F, Loi S, Piccart M, Michiels S \& Sotiriou C 2012 Gene modules and response to neoadjuvant chemotherapy in breast cancer subtypes: a pooled analysis. Journal of Clinical Oncology 30 1996-2004. (doi:10.1200/JCO.2011.39.5624)

Jiang X \& Shapiro DJ 2014 The immune system and inflammation in breast cancer. Molecular and Cellular Endocrinology 382 673-682. (doi:10.1016/ j.mce.2013.06.003)

Jinquan T, Vorum H, Larsen CG, Madsen P, Rasmussen HH, Gesser B, Etzerodt M, Honore B, Celis JE \& Thestrup-Pedersen K 1996 Psoriasin: a novel chemotactic protein. Journal of Investigative Dermatology 107 5-10. (doi:10.1111/1523-1747.ep12294284)

Johnston SR, Saccani-Jotti G, Smith IE, Salter J, Newby J, Coppen M, Ebbs SR \& Dowsett M 1995 Changes in estrogen receptor, progesterone receptor, and pS2 expression in tamoxifen-resistant human breast cancer. Cancer Research 55 3331-3338.

Jones SA, Scheller J \& Rose-John S 2011 Therapeutic strategies for the clinical blockade of IL-6/gp130 signaling. Journal of Clinical Investigation 121 3375-3383. (doi:10.1172/JCI57158)

Jonsson P, Katchy A \& Williams C 2014 Support of a bi-faceted role of estrogen receptor $\beta$ (ER $\beta)$ in ER $\alpha$-positive breast cancer cells. Endocrine-Related Cancer 21 143-160. (doi:10.1530/ERC-13-0444)

Jorcyk CL, Holzer RG \& Ryan RE 2006 Oncostatin M induces cell detachment and enhances the metastatic capacity of T-47D human breast carcinoma cells. Cytokine 33 323-336. (doi:10.1016/j.cyto.2006. 03.004)

Kaklamani V 2006 A genetic signature can predict prognosis and response to therapy in breast cancer: oncotype DX. Expert Review of Molecular Diagnostics 6 803-809. (doi:10.1586/14737159.6.6.803)

Kalyuga M, Gallego-Ortega D, Lee HJ, Roden DL, Cowley MJ, Caldon CE, Stone A, Allerdice SL, Valdes-Mora F, Launchbury R et al. 2012 ELF5 
suppresses estrogen sensitivity and underpins the acquisition of antiestrogen resistance in luminal breast cancer. PLoS Biology $\mathbf{1 0}$ e1001461. (doi:10.1371/journal.pbio.1001461)

Kastl SP, Speidl WS, Kaun C, Katsaros KM, Rega G, Afonyushkin T, Bochkov VN, Valent P, Assadian A, Hagmueller GW et al. 2008 In human macrophages the complement component $\mathrm{C} 5 \mathrm{a}$ induces the expression of oncostatin M via AP-1 activation. Arteriosclerosis, Thrombosis, and Vascular Biology 28 498-503. (doi:10.1161/ATVBAHA.107.160580)

Kluger HM, Dolled-Filhart M, Rodov S, Kacinski BM, Camp RL \& Rimm DL 2004 Macrophage colony-stimulating factor- 1 receptor expression is associated with poor outcome in breast cancer by large cohort tissue microarray analysis. Clinical Cancer Research 10 173-177. (doi:10.1158/ 1078-0432.CCR-0699-3)

Kronblad A, Hedenfalk I, Nilsson E, Pahlman S \& Landberg G 2005 ERK1/2 inhibition increases antiestrogen treatment efficacy by interfering with hypoxia-induced downregulation of ER $\alpha$ : a combination therapy potentially targeting hypoxic and dormant tumor cells. Oncogene $\mathbf{2 4}$ 6835-6841. (doi:10.1038/sj.onc.1208830)

Kuukasjarvi T, Kononen J, Helin H, Holli K \& Isola J 1996 Loss of estrogen receptor in recurrent breast cancer is associated with poor response to endocrine therapy. Journal of Clinical Oncology 14 2584-2589.

Kwan ML, Habel LA, Slattery ML \& Caan B 2007 NSAIDs and breast cancer recurrence in a prospective cohort study. Cancer Causes \& Control 18 613-620. (doi:10.1007/s10552-007-9003-y)

Lapidus RG, Nass SJ \& Davidson NE 1998 The loss of estrogen and progesterone receptor gene expression in human breast cancer. Journal of Mammary Gland Biology and Neoplasia 3 85-94. (doi:10.1023/ A:1018778403001)

Lehmann BD, Bauer JA, Chen X, Sanders ME, Chakravarthy AB, Shyr Y \& Pietenpol JA 2011 Identification of human triple-negative breast cancer subtypes and preclinical models for selection of targeted therapies. Journal of Clinical Investigation 121 2750-2767. (doi:10.1172/JCI45014)

Levano KS, Jung EH \& Kenny PA 2011 Breast cancer subtypes express distinct receptor repertoires for tumor-associated macrophage derived cytokines. Biochemical and Biophysical Research Communications $\mathbf{4 1 1}$ 107-110. (doi:10.1016/j.bbrc.2011.06.102)

Lewis JS \& Jordan VC 2005 Selective estrogen receptor modulators (SERMs): mechanisms of anticarcinogenesis and drug resistance. Mutation Research 591 247-263. (doi:10.1016/j.mrfmmm.2005.02.028)

Lewis CE \& Pollard JW 2006 Distinct role of macrophages in different tumor microenvironments. Cancer Research 66 605-612. (doi:10.1158/ 0008-5472.CAN-05-4005)

Leygue E, Snell L, Hiller T, Dotzlaw H, Hole K, Murphy LC \& Watson PH 1996 Differential expression of psoriasin messenger RNA between in situ and invasive human breast carcinoma. Cancer Research 56 4606-4609.

Lim E, Metzger-Filho O \& Winer EP 2012 The natural history of hormone receptor-positive breast cancer. Oncology 26 688-694.

Liu S, Lachapelle J, Leung S, Gao D, Foulkes WD \& Nielsen TO 2012 CD8 $^{+}$ lymphocyte infiltration is an independent favorable prognostic indicator in basal-like breast cancer. Breast Cancer Research 14 R48. (doi:10.1186/bcr3148)

Loi S, Haibe-Kains B, Desmedt C, Wirapati P, Lallemand F, Tutt AM, Gillet C, Ellis P, Ryder K, Reid JF et al. 2008 Predicting prognosis using molecular profiling in estrogen receptor-positive breast cancer treated with tamoxifen. BMC Genomics 9 239. (doi:10.1186/1471-2164-9-239)

Mahmoud SM, Paish EC, Powe DG, Macmillan RD, Grainge MJ, Lee AH, Ellis IO \& Green AR 2011 Tumor-infiltrating CD8 ${ }^{+}$lymphocytes predict clinical outcome in breast cancer. Journal of Clinical Oncology 29 1949-1955. (doi:10.1200/JCO.2010.30.5037)

Man J \& Zhang X 2011 CUEDC2: an emerging key player in inflammation and tumorigenesis. Protein \& Cell 2 699-703. (doi:10.1007/s13238-011-1089-z)

Massarweh S, Osborne CK, Jiang S, Wakeling AE, Rimawi M, Mohsin SK, Hilsenbeck S \& Schiff R 2006 Mechanisms of tumor regression and resistance to estrogen deprivation and fulvestrant in a model of estrogen receptor-positive, HER-2/neu-positive breast cancer. Cancer Research 66 8266-8273. (doi:10.1158/0008-5472.CAN-05-4045)
Medrek C, Ponten F, Jirstrom K \& Leandersson K 2012 The presence of tumor associated macrophages in tumor stroma as a prognostic marker for breast cancer patients. BMC Cancer 12 306. (doi:10.1186/1471-240712-306)

Miller TW, Balko JM \& Arteaga CL 2011 Phosphatidylinositol 3-kinase and antiestrogen resistance in breast cancer. Journal of Clinical Oncology 29 4452-4461. (doi:10.1200/JCO.2010.34.4879)

Motomura K, Ishitobi M, Komoike Y, Koyama H, Nagase H, Inaji H \& Noguchi S 2010 Expression of estrogen receptor beta and phosphorylation of estrogen receptor alpha serine 167 correlate with progressionfree survival in patients with metastatic breast cancer treated with aromatase inhibitors. Oncology 79 55-61. (doi:10.1159/000319540)

Murphy LC \& Leygue E 2012 The role of estrogen receptor- $\beta$ in breast cancer. Seminars in Reproductive Medicine 30 5-13. (doi:10.1055/ s-0031-1299592)

Murphy LC \& Watson PH 2006 Is oestrogen receptor- $\beta$ a predictor of endocrine therapy responsiveness in human breast cancer? Endocrine-Related Cancer 13 327-334. (doi:10.1677/erc.1.01141)

Murphy LC \& Watson P 2002 Steroid receptors in human breast tumorigenesis and breast cancer progression. Biomedicine \& Pharmacotherapy 56 65-77. (doi:10.1016/S0753-3322(01)00157-3)

Murphy LC, Leygue E, Niu Y, Snell L, Ho SM \& Watson PH 2002 Relationship of coregulator and oestrogen receptor isoform expression to de novo tamoxifen resistance in human breast cancer. British Journal of Cancer 87 1411-1416. (doi:10.1038/sj.bjc.6600654)

Murphy LC, Peng B, Lewis A, Davie JR, Leygue E, Kemp A, Ung K, Vendetti $\mathrm{M} \&$ Shiu R 2005 Inducible upregulation of oestrogen receptor- $\beta 1$ affects oestrogen and tamoxifen responsiveness in MCF7 human breast cancer cells. Journal of Molecular Endocrinology 34 553-566. (doi:10.1677/jme.1.01688)

Murphy LC, Seekallu SV \& Watson PH 2011 Clinical significance of estrogen receptor phosphorylation. Endocrine-Related Cancer 18 R1-R14. (doi:10.1677/ERC-10-0070)

Musgrove EA \& Sutherland RL 2009 Biological determinants of endocrine resistance in breast cancer. Nature Reviews. Cancer 9 631-643. (doi:10. 1038/nrc2713)

Nagaraj G, Ellis MJ \& Ma CX 2012 The natural history of hormone receptorpositive breast cancer: attempting to decipher an intriguing concept. Oncology 26 696-697, 700.

Nasser MW, Qamri Z, Deol YS, Ravi J, Powell CA, Trikha P, Schwendener RA, Bai XF, Shilo K, Zou X et al. 2012 S100A7 enhances mammary tumorigenesis through upregulation of inflammatory pathways. Cancer Research 72 604-615. (doi:10.1158/0008-5472.CAN-11-0669)

Naugler WE \& Karin M 2008 The wolf in sheep's clothing: the role of interleukin-6 in immunity, inflammation and cancer. Trends in Molecular Medicine 14 109-119. (doi:10.1016/j.molmed.2007.12.007)

Oh AS, Lorant LA, Holloway JN, Miller DL, Kern FG \& El-Ashry D 2001 Hyperactivation of MAPK induces loss of ER $\alpha$ expression in breast cancer cells. Molecular Endocrinology 15 1344-1359. (doi:10.1210/mend.15.8.0678)

Oida K, Matsuda A, Jung K, Xia Y, Jang H, Amagai Y, Ahn G, Nishikawa S, Ishizaka S, Jensen-Jarolim E et al. 2014 Nuclear factor- $\mathrm{KB}$ plays a critical role in both intrinsic and acquired resistance against endocrine therapy in human breast cancer cells. Scientific Reports 4 4057. (doi:10.1038/ srep04057)

Osborne CK \& Schiff R 2011 Mechanisms of endocrine resistance in breast cancer. Annual Review of Medicine 62 233-247. (doi:10.1146/annurevmed-070909-182917)

Osborne CK, Bardou V, Hopp TA, Chamness GC, Hilsenbeck SG, Fuqua SA, Wong J, Allred DC, Clark GM \& Schiff R 2003 Role of the estrogen receptor coactivator AIB1 (SRC-3) and HER-2/neu in tamoxifen resistance in breast cancer. Journal of the National Cancer Institute 95 353-361. (doi:10.1093/jnci/95.5.353)

Pages F, Galon J, Dieu-Nosjean MC, Tartour E, Sautes-Fridman C \& Fridman WH 2010 Immune infiltration in human tumors: a prognostic factor that should not be ignored. Oncogene 29 1093-1102. (doi:10.1038/onc. 2009.416) http://erc.endocrinology-journals.org DOI: 10.1530/ERC-14-0096
(C) 2015 Society for Endocrinology Printed in Great Britain 
Pan X, Zhou T, Tai YH, Wang C, Zhao J, Cao Y, Chen Y, Zhang PJ, Yu M, Zhen $\mathrm{C}$ et al. 2011 Elevated expression of CUEDC2 protein confers endocrine resistance in breast cancer. Nature Medicine 17 708-714. (doi:10.1038/nm.2369)

Patani N \& Martin LA 2014 Understanding response and resistance to oestrogen deprivation in ER-positive breast cancer. Molecular and Cellular Endocrinology 382 683-694. (doi:10.1016/j.mce.2013.09.038)

Peddi PF, Ellis MJ \& Ma C 2012 Molecular basis of triple negative breast cancer and implications for therapy. International Journal of Breast Cancer 2012 217185. (doi:10.1155/2012/217185)

Pradhan M, Bembinster LA, Baumgarten SC \& Frasor J 2010 Proinflammatory cytokines enhance estrogen-dependent expression of the multidrug transporter gene $A B C G 2$ through estrogen receptor and NFאB cooperativity at adjacent response elements. Journal of Biological Chemistry 285 31100-31106. (doi:10.1074/jbc.M110.155309)

Pradhan M, Baumgarten SC, Bembinster LA \& Frasor J 2012 CBP mediates NF- $\mathrm{kB}$-dependent histone acetylation and estrogen receptor recruitment to an estrogen response element in the BIRC3 promoter. Molecular and Cellular Biology 32 569-575. (doi:10.1128/MCB.05869-11)

Prat A, Parker JS, Karginova O, Fan C, Livasy C, Herschkowitz JI, He X \& Perou CM 2010 Phenotypic and molecular characterization of the claudin-low intrinsic subtype of breast cancer. Breast Cancer Research 12 R68. (doi:10.1186/bcr2635)

Queen MM, Ryan RE, Holzer RG, Keller-Peck CR \& Jorcyk CL 2005 Breast cancer cells stimulate neutrophils to produce oncostatin M: potential implications for tumor progression. Cancer Research 65 8896-8904. (doi:10.1158/0008-5472.CAN-05-1734)

Reiman JM, Kmieciak M, Manjili MH \& Knutson KL 2007 Tumor immunoediting and immunosculpting pathways to cancer progression. Seminars in Cancer Biology 17 275-287. (doi:10.1016/j. semcancer.2007.06.009)

Reiman JM, Knutson KL \& Radisky DC 2010 Immune promotion of epithelial-mesenchymal transition and generation of breast cancer stem cells. Cancer Research 70 3005-3008. (doi:10.1158/0008-5472. CAN-09-4041)

Richards CD 2013 The enigmatic cytokine oncostatin M and roles in disease. ISRN Inflammation 2013 512103. (doi:10.1155/2013/512103)

Riggins RB, Schrecengost RS, Guerrero MS \& Bouton AH 2007 Pathways to tamoxifen resistance. Cancer Letters 256 1-24. (doi:10.1016/j.canlet. 2007.03.016)

Rincon M, Broadwater G, Harris L, Crocker A, Weaver D, Dressler L, Berry D, Sutton L, Michaelson R, Messino M et al. 2006 Interleukin-6, multidrug resistance protein-1 expression and response to paclitaxel in women with metastatic breast cancer: results of cancer and leukemia group B trial 159806. Breast Cancer Research and Treatment 100 301-308. (doi:10.1007/ s10549-006-9251-7)

Robinson JL, Macarthur S, Ross-Innes CS, Tilley WD, Neal DE, Mills IG \& Carroll JS 2011 Androgen receptor driven transcription in molecular apocrine breast cancer is mediated by FoxA1. EMBO Journal 30 3019-3027. (doi:10.1038/emboj.2011.216)

Royuela M, Ricote M, Parsons MS, Garcia-Tunon I, Paniagua R \& de Miguel MP 2004 Immunohistochemical analysis of the IL-6 family of cytokines and their receptors in benign, hyperplasic, and malignant human prostate. Journal of Pathology 202 41-49. (doi:10.1002/path.1476)

Rubio MF, Werbajh S, Cafferata EG, Quaglino A, Colo GP, Nojek IM, Kordon EC, Nahmod VE \& Costas MA 2006 TNF- $\alpha$ enhances estrogeninduced cell proliferation of estrogen-dependent breast tumor cells through a complex containing nuclear factor-kappa B. Oncogene $\mathbf{2 5}$ 1367-1377. (doi:10.1038/sj.onc.1209176)

Sabnis GJ, Goloubeva O, Chumsri S, Nguyen N, Sukumar S \& Brodie AM 2011 Functional activation of the estrogen receptor- $\alpha$ and aromatase by the HDAC inhibitor entinostat sensitizes ER-negative tumors to letrozole. Cancer Research 71 1893-1903. (doi:10.1158/0008-5472.CAN-10-2458)

Sas L, Lardon F, Vermeulen PB, Hauspy J, Van Dam P, Pauwels P, Dirix LY \& Van Laere SJ 2012 The interaction between ER and NFKB in resistance to endocrine therapy. Breast Cancer Research 14 212. (doi:10.1186/bcr3196)
Schiff R \& Osborne CK 2005 Endocrinology and hormone therapy in breast cancer: new insight into estrogen receptor- $\alpha$ function and its implication for endocrine therapy resistance in breast cancer. Breast Cancer Research 7 205-211. (doi:10.1186/bcr1287)

Schiff R, Massarweh SA, Shou J, Bharwani L, Mohsin SK \& Osborne CK 2004 Cross-talk between estrogen receptor and growth factor pathways as a molecular target for overcoming endocrine resistance. Clinical Cancer Research 10 331S-336S. (doi:10.1158/1078-0432.CCR-031212)

Schreiber RD, Old LJ \& Smyth MJ 2011 Cancer immunoediting: integrating immunity's roles in cancer suppression and promotion. Science $\mathbf{3 3 1}$ 1565-1570. (doi:10.1126/science.1203486)

Schroder JM \& Harder J 2006 Antimicrobial skin peptides and proteins. Cellular and Molecular Life Sciences 63 469-486. (doi:10.1007/s00018-005-5364-0)

Scott DL 2012 Biologics-based therapy for the treatment of rheumatoid arthritis. Clinical Pharmacology and Therapeutics 91 30-43. (doi:10.1038/ clpt.2011.278)

Shou J, Massarweh S, Osborne CK, Wakeling AE, Ali S, Weiss H \& Schiff R 2004 Mechanisms of tamoxifen resistance: increased estrogen receptorHER2/neu cross-talk in ER/HER2-positive breast cancer. Journal of the National Cancer Institute 96 926-935. (doi:10.1093/jnci/djh166)

Simanski M, Rademacher F, Schroder L, Schumacher HM, Glaser R \& Harder J 2013 IL-17A and IFN- $\gamma$ synergistically induce RNase 7 expression via STAT3 in primary keratinocytes. PLOS ONE 8 e59531. (doi:10.1371/journal.pone.0059531)

Skliris GP, Leygue E, Curtis-Snell L, Watson PH \& Murphy LC 2006 Expression of oestrogen receptor- $\beta$ in oestrogen receptor- $\alpha$ negative human breast tumours. British Journal of Cancer 95 616-626. (doi:10.1038/sj.bjc.6603295)

Skliris GP, Lewis A, Emberley E, Peng B, Weebadda WK, Kemp A, Davie JR, Shiu RP, Watson PH \& Murphy LC 2007 Estrogen receptor- $\beta$ regulates psoriasin (S100A7) in human breast cancer. Breast Cancer Research and Treatment 104 75-85. (doi:10.1007/s10549-006-9390-x)

Skliris GP, Leygue E, Watson PH \& Murphy LC 2008 Estrogen receptor alpha negative breast cancer patients: estrogen receptor beta as a therapeutic target. Journal of Steroid Biochemistry and Molecular Biology 109 1-10. (doi:10.1016/j.jsbmb.2007.12.010)

Skliris GP, Nugent ZJ, Rowan BG, Penner CR, Watson PH \& Murphy LC 2010 A phosphorylation code for oestrogen receptor- $\alpha$ predicts clinical outcome to endocrine therapy in breast cancer. Endocrine-Related Cancer 17 589-597. (doi:10.1677/ERC-10-0030)

Speirs V, Kerin MJ, Walton DS, Newton CJ, Desai SB \& Atkin SL 2000 Direct activation of oestrogen receptor- $\alpha$ by interleukin- 6 in primary cultures of breast cancer epithelial cells. British Journal of Cancer 82 1312-1316. (doi:10.1054/bjoc.1999.1097)

Stearns V, Zhou Q \& Davidson NE 2007 Epigenetic regulation as a new target for breast cancer therapy. Cancer Investigation 25 659-665. (doi:10.1080/07357900701719234)

Stossi F, Madak-Erdogan Z \& Katzenellenbogen BS 2012a Macrophageelicited loss of estrogen receptor- $\alpha$ in breast cancer cells via involvement of MAPK and c-Jun at the ESR1 genomic locus. Oncogene 31 1825-1834. (doi:10.1038/onc.2011.370)

Stossi F, Madak-Erdogan Z, Ventrella R, \& Katzenellenbogen BS $2012 b$ Macrophage-derived amphiregulin causes estrogen receptor- $\alpha$ downregulation in tamoxifen-resistant breast cancer cells. Hormone Dependent Tumors (Translational), The Endocrine Society's 94th Annual Meeting and Expo, June 23-26, 2012 - Houston, TX, USA. Presentation number OR0504-OR05-04. (doi:10.1210/endo-meetings.2012.33.03_MeetingAbstracts. OR05-4).

Sullivan NJ, Sasser AK, Axel AE, Vesuna F, Raman V, Ramirez N, Oberyszyn TM \& Hall BM 2009 Interleukin-6 induces an epithelial-mesenchymal transition phenotype in human breast cancer cells. Oncogene 28 2940-2947. (doi:10.1038/onc.2009.180)

Taniguchi K \& Karin M 2014 IL-6 and related cytokines as the critical lynchpins between inflammation and cancer. Seminars in Immunology 26 54-74. (doi:10.1016/j.smim.2014.01.001) 
Teschendorff AE, Journee M, Absil PA, Sepulchre R \& Caldas C 2007a Elucidating the altered transcriptional programs in breast cancer using independent component analysis. PLoS Computational Biology 3 e161. (doi:10.1371/journal.pcbi.0030161)

Teschendorff AE, Miremadi A, Pinder SE, Ellis IO \& Caldas C 2007b An immune response gene expression module identifies a good prognosis subtype in estrogen receptor negative breast cancer. Genome Biology $\mathbf{8}$ R157. (doi:10.1186/gb-2007-8-8-r157)

Tiffen PG, Omidvar N, Marquez-Almuina N, Croston D, Watson CJ \& Clarkson RW 2008 A dual role for oncostatin M signaling in the differentiation and death of mammary epithelial cells in vivo. Molecular Endocrinology 22 2677-2688. (doi:10.1210/me.2008-0097)

Underhill-Day N \& Heath JK 2006 Oncostatin M (OSM) cytostasis of breast tumor cells: characterization of an OSM receptor $\beta$-specific kernel. Cancer Research 66 10891-10901. (doi:10.1158/0008-5472.CAN-06-1766)

Vesuna F, Lisok A, Kimble B, Domek J, Kato Y, van der Groep P, Artemov D, Kowalski J, Carraway H, van Diest P et al. 2012 Twist contributes to hormone resistance in breast cancer by downregulating estrogen receptor- $\alpha$. Oncogene 31 3223-3234. (doi:10.1038/onc.2011.483)

Vlaicu P, Mertins P, Mayr T, Widschwendter P, Ataseven B, Hogel B, Eiermann W, Knyazev P \& Ullrich A 2013 Monocytes/macrophages support mammary tumor invasivity by co-secreting lineage-specific EGFR ligands and a STAT3 activator. BMC Cancer 13 197. (doi:10.1186/ 1471-2407-13-197)

Vona-Davis L \& Rose DP 2013 The obesity-inflammation-eicosanoid axis in breast cancer. Journal of Mammary Gland Biology and Neoplasia 18 291-307. (doi:10.1007/s10911-013-9299-z)

Wang X, Belguise K, Kersual N, Kirsch KH, Mineva ND, Galtier F, Chalbos D \& Sonenshein GE 2007 Oestrogen signalling inhibits invasive phenotype by repressing RelB and its target BCL2. Nature Cell Biology 9 470-478. (doi:10.1038/ncb1559)

Wang X, Belguise K, O'Neill CF, Sanchez-Morgan N, Romagnoli M, Eddy SF, Mineva ND, Yu Z, Min C, Trinkaus-Randall V et al. 2009 RelB NF-кB represses estrogen receptor $\alpha$ expression via induction of the zinc finger protein Blimp1. Molecular and Cellular Biology 29 3832-3844. (doi:10.1128/MCB.00032-09)

Webb M, Emberley ED, Lizardo M, Alowami S, Qing G, Alfia'ar A, SnellCurtis LJ, Niu Y, Civetta A, Myal Y et al. 2005 Expression analysis of the mouse $\mathrm{S} 100 \mathrm{~A} 7 /$ psoriasin gene in skin inflammation and mammary tumorigenesis. BMC Cancer 5 17. (doi:10.1186/1471-2407-5-17)

Weitsman GE, Skliris G, Ung K, Peng B, Younes M, Watson PH \& Murphy LC 2006 Assessment of multiple different estrogen receptor- $\beta$ antibodies for their ability to immunoprecipitate under chromatin immunoprecipitation conditions. Breast Cancer Research and Treatment 100 23-31. (doi:10.1007/s10549-006-9229-5)

West NR \& Watson PH 2010 S100A7 (psoriasin) is induced by the proinflammatory cytokines oncostatin-M and interleukin-6 in human breast cancer. Oncogene 29 2083-2092. (doi:10.1038/onc.2009.488)
West NR, Milne K, Truong PT, Macpherson N, Nelson BH \& Watson PH 2011 Tumor-infiltrating lymphocytes predict response to anthracycline-based chemotherapy in estrogen receptor-negative breast cancer. Breast Cancer Research 13 R126. (doi:10.1186/bcr3072)

West NR, Murphy LC \& Watson PH 2012 Oncostatin M suppresses oestrogen receptor- $\alpha$ expression and is associated with poor outcome in human breast cancer. Endocrine-Related Cancer 19 181-195. (doi:10.1530/ERC-11-0326)

West NR, Murray JI \& Watson PH 2014 Oncostatin-M promotes phenotypic changes associated with mesenchymal and stem cell-like differentiation in breast cancer. Oncogene 33 1485-1494. (doi:10.1038/ onc.2013.105)

Wolf R, Howard OM, Dong HF, Voscopoulos C, Boeshans K, Winston J, Divi R, Gunsior M, Goldsmith P, Ahvazi B et al. 2008 Chemotactic activity of S100A7 (Psoriasin) is mediated by the receptor for advanced glycation end products and potentiates inflammation with highly homologous but functionally distinct S100A15. Journal of Immunology 181 1499-1506. (doi:10.4049/jimmunol.181.2.1499)

Wolk K, Witte E, Wallace E, Docke WD, Kunz S, Asadullah K, Volk HD, Sterry W \& Sabat R 2006 IL-22 regulates the expression of genes responsible for antimicrobial defense, cellular differentiation, and mobility in keratinocytes: a potential role in psoriasis. European Journal of Immunology 36 1309-1323. (doi:10.1002/eji.200535503)

Yan Y, Li X, Blanchard A, Bramwell VH, Pritchard KI, Tu D, Shepherd L, Myal Y, Penner C, Watson PH et al. 2013 Expression of both estrogen receptor-beta 1 (ER- $\beta 1$ ) and its co-regulator steroid receptor RNA activator protein (SRAP) are predictive for benefit from tamoxifen therapy in patients with estrogen receptor-alpha (ER- $\alpha$ )-negative early breast cancer (EBC). Annals of Oncology 24 1986-1993. (doi:10.1093/annonc/mdt132)

Ye Y, Xiao Y, Wang W, Yearsley K, Gao JX, Shetuni B \& Barsky SH 2010 ER $\alpha$ signaling through slug regulates E-cadherin and EMT. Oncogene 29 1451-1462. (doi:10.1038/onc.2009.433)

Younes M \& Honma N 2011 Estrogen receptor $\beta$. Archives of Pathology \& Laboratory Medicine 135 63-66. (doi:10.1043/2010-0448-RAR.1)

Zeisberg M \& Neilson EG 2009 Biomarkers for epithelial-mesenchymal transitions. Journal of Clinical Investigation 119 1429-1437. (doi:10.1172/JCI36183)

Zhang XH, Giuliano M, Trivedi MV, Schiff R \& Osborne CK 2013 Metastasis dormancy in estrogen receptor-positive breast cancer. Clinical Cancer Research 19 6389-6397. (doi:10.1158/1078-0432.CCR-13-0838)

Zitvogel L, Galluzzi L, Smyth MJ \& Kroemer G 2013 Mechanism of action of conventional and targeted anticancer therapies: reinstating immunosurveillance. Immunity 39 74-88. (doi:10.1016/j.immuni. 2013.06.014)

Zwart W, Theodorou V \& Carroll JS 2011 Estrogen receptor-positive breast cancer: a multidisciplinary challenge. Wiley Interdisciplinary Reviews. Systems Biology and Medicine 3 216-230. (doi:10.1002/wsbm.109)

Received in final form 11 November 2014

Accepted 17 November 2014

Made available online as an Accepted Preprint

17 November 2014 http://erc.endocrinology-journals.org DOI: 10.1530/ERC-14-0096
(C) 2015 Society for Endocrinology Printed in Great Britain
Published by Bioscientifica Ltd. 